\title{
DE-ESCALATION OF IMMUNOMODULATOR AND BIOLOGICAL THERAPY IN INFLAMMATORY BOWEL DISEASE
}

Thomas P Chapman*, Catarina Frias Gomes*, Edouard Louis, Jean-Frederic Colombel, Jack Satsangi

* Joint first authors

Translational Gastroenterology Unit, Nuffield Department of Experimental Medicine, University of Oxford, Oxford, UK (T P Chapman DPhil, Prof J Satsangi DPhil); Surgical Department, Gastroenterology Division, Hospital Beatriz Angelo, Loures, Portugal (C Frias Gomes MD); Department of Gastroenterology, CHU Liège University Hospital, Liège, Belgium (Prof E Louis PhD); and The Dr Henry D Janowitz Division of Gastroenterology, Icahn School of Medicine at Mount Sinai, New York, NY, USA (Prof J-F Colombel MD)

Treatment strategies for inflammatory bowel disease (IBD) focus on the induction and longterm maintenance of deep remission to avoid complications of active disease and improve longterm outcomes. Medical therapies for IBD, notably the increasingly widespread use of biological therapy, are often effective at controlling disease, but these drugs are associated with substantial adverse events, which together with other factors-including increasing treatment costs and patient preferences-leads to concerns regarding indefinite use of medical therapy. Consequently, the need to consider the safety and feasibility of drug de-escalation once IBD remission has been achieved is clear. Here, we review the current evidence surrounding deescalation of immunomodulator and biological therapy in Crohn's disease and ulcerative colitis. We discuss strategies for de-escalation, including the selection of patients who are appropriate for treatment de-escalation and the use of proactive drug monitoring, and review the evidence on subsequent optimal follow-up. We conclude by proposing an algorithm to guide de-escalation decisions, and highlight future perspectives, including the potential effect of emerging medication and personalised medicine for these diseases.

\section{Introduction}

Therapeutic strategies for inflammatory bowel disease (IBD) have substantially changed over the past decade, with widespread acknowledgment that deep remission (defined as clinical, biochemical, and endoscopic remission) is associated with better long-term outcomes. ${ }^{1}$ Consequently, patients are increasingly treated with biological agents, immunomodulators, or both, in early stages of disease. Two key studies support this approach: CALM ${ }^{2}$ and REACT. ${ }^{3}$ The CALM study showed the benefits of prompt escalation with anti-TNF therapy in patients with early Crohn's disease, with a higher proportion of those assigned to tighter disease control achieving mucosal healing and clinical remission. ${ }^{2}$ In the REACT study, patients with Crohn's disease who received accelerated combination therapy with anti-TNF and antimetabolite drugs had a lower prevalence of major adverse outcomes, including surgery, hospital admission, and serious disease- related complications, than those receiving conventional therapy; however, 
these adverse outcomes were secondary endpoints, and no difference was noted in the primary endpoint of steroid-free remission. ${ }^{3}$

Aggressive escalation of medical therapy early in the disease course appears to improve disease control, but once remission has been achieved both clinicians and patients face challenging questions about the timing and feasibility of treatment de-escalation. In this Review, we address the elective discontinuation of immunomodulator and biological therapy for patients who have achieved sustained clinical remission. The issues surrounding discontinuation of therapy for other reasons, including pregnancy, planned surgery, and intercurrent infection or malignancy, are addressed comprehensively elsewhere. . $^{4-8}$

Undoubtedly, the safety of immunomodulators and biological therapy is a key issue for clinicians, but the risk of drug-related adverse events must be balanced against the harmful effects of losing disease control. ${ }^{9}$

Particular concern has surrounded the risk of infectious complications and drug-related lymphoproliferative dis-orders. Registry data have confirmed the risks of monotherapy and have highlighted that patients on combination therapy are at greatest risk.10,11 Withdrawal of a thiopurine drug reduces the risk of lymphoproliferative disorders, with a prospective study showing a lower incidence of such adverse events in patients with IBD who discontinued thiopurine treatment ( 0.20 per 1000 patient-years) and those who were never exposed to thiopurine (0.26 per 1000 patient-years) compared with those who continued thiopurine treatment ( 0.90 per 1000 patient-years; $\mathrm{p}=0.0054) .{ }^{12}$ Taken together, these data suggest that de-escalation of drug therapy, in particular combination therapy, might reduce the risk of serious drug-related adverse events.

De-escalation of therapy also provides cost savings, an important consideration at a time of increasing pressure on health-care budgets worldwide. The COIN study ${ }^{13}$ from the Netherlands showed that IBD healthcare costs are predominantly driven by the cost of medication, in particular anti-TNF therapy, which accounted for $64 \%$ of the total cost in Crohn's disease and $31 \%$ of the total cost in ulcerative colitis. Data from the TAXIT trial14 showed that de-escalation of infliximab dosing, based on trough concentrations, led to a $28 \%$ reduction in drug costs both for patients with Crohn's disease and those with ulcerative colitis who had initially shown a full or partial response to infliximab maintenance therapy, without impairing clinical outcome. However, both studies ${ }^{13,14}$ predate the arrival of biosimilars, which have provided significant cost savings. The cost-effectiveness of de-escalation versus non-de-escalation, based on infliximab trough concentrations, has been compared in virtual cohorts of patients with Crohn's disease in remission. ${ }^{15}$ Over the modelled 2-year follow-up period, infliximab de-escalation, based on trough concentrations, was predicted to lead to a cost saving of $6.1 \%$, corresponding to $€ 25.4$ million per 10000 patients. The use of infliximab biosimilars resulted in a lower, but still substantial, absolute cost saving of €13.8 million per 10000 patients. 15

In this Review, we discuss the best available evidence on de-escalation of immunomodulators and biological therapy for patients with IBD in remission, considering these treatments both separately and in combination. We propose an algorithm to guide de-escalation decisions and conclude by highlighting noteworthy future perspectives, including the potential effect of personalised medicine and emerging therapies. 


\section{Withdrawal of immunomodulator monotherapy}

Four randomised controlled trials (RCTs) have evaluated the withdrawal of immunomodulator monotherapy in patients with Crohn's disease in clinical remission. ${ }^{16-18,20}$ All of the studies reported higher relapse in the withdrawal groups. 30 In a multicentre, double-blind, non-inferiority withdrawal study, patients with Crohn's disease in clinical remission on azathioprine for at least 42 months were randomly assigned to either continue azathioprine or receive a placebo. The relapse rate was higher in the placebo group than in the azathioprine group (nine [21\%] of 43 patients $v s$ three [8\%] of 40) at 18 months. The authors concluded that withdrawal of azathioprine was not equivalent to continuation with regard to maintenance of remission; as a result, azathioprine maintenance therapy should be continued beyond 3.5 years of treatment. ${ }^{17}$ A follow-up of this study, which was limited by the small number of patients recruited $(n=66)$, showed that the cumulative probability of relapse was $52.8 \%$ (SE 7.1) at 3 years and reached $62.7 \%$ (7.2) at 5 years. Thus, azathioprine withdrawal was associated with a high-risk of relapse even after a long period of clinical remission. ${ }^{31}$ In a second study, 52 patients with Crohn's disease who has been treated with azathioprine for at least 48 months were randomly assigned to either continue azathioprine or switch to placebo. The proportion of patients in remission after 1 year of follow-up was lower in the placebo group (76\% [SD 8]) than in the azathioprine group (96\% [4]) $\mathrm{p}=0.035$, but this statistically significant difference was lost after 2 years. ${ }^{16} \mathrm{~A}$ Cochrane meta-analysis based on data from four studies with follow-up between 12 and 24 months indicated that overall, 36 (32\%) of 111 patients relapsed following azathioprine withdrawal in comparison with $14(13 \%)$ of 104 patients who relapsed after continuing azathioprine therapy (relative risk 0.42 [95\% CI 0.4-0.72]; $\mathrm{p}=0.002$ ). ${ }^{32}$ Retrospective studies have reported higher relapse rates following the withdrawal of immunomodulators; $14-38 \%$ at 12 months, $39-71 \%$ at 24 months, $53-85 \%$ at 36 months, and $63-85 \%$ at 60 months. ${ }^{30}$ None of these studies assessed azathioprine metabolite concentrations, which might prove to be important in predicting relapse following de-escalation of thiopurine monotherapy.

A small RCT involving patients with ulcerative colitis reported a relapse rate of $61 \%(17 / 28)$ for patients in long term remission when azathioprine was withdrawn versus $31 \%(8 / 26)$ in those continuing their azathioprine regimen $(\mathrm{p}<0.001)$ by the end of the first year of followup. ${ }^{19}$ Importantly, patients who had taken azathioprine for 6 months before de-escalation were included, which might explain the high relapse rates. Longer follow-up times have been assessed in retrospective cohort studies. Relapse rates ranged from $43-65 \%$ at 5 years to $75-87 \%$ over longer periods..$^{30}$ Finally, a retrospective study of 70 patients with IBD (48 patients with Crohn's disease and 22 with ulcerative colitis) evaluated relapse rate after methotrexate withdrawal. The probability of remaining in remission was higher when methotrexate was continued $(90 \%)$ than if discontinued (21\%) after 12 months of follow-up, with no difference found between patients with Crohn's disease and those with ulcerative colitis. ${ }^{33}$ We have summarised the RCTs of immunomodulator withdrawal in table 1.

In summary, withdrawal of immunomodulator monotherapy (thiopurine or methotrexate) is associated with a substantial risk of relapse both in patients with Crohn's disease and those with ulcerative colitis, even among patients who have achieved long-term remission. These data need to be weighed against the evidence for the cumulative increased risk of serious complications 
with long-term therapy and the suggestion that a period off therapy will significantly reduce the risk of drug-related lymphoma. ${ }^{12}$

\section{Withdrawal of the immunomodulator from combination therapy}

In an open-label RCT, ${ }^{28}$ patients with Crohn's disease receiving combination therapy with immunomodulators and infliximab for at least 6 months were randomly assigned to either continue or stop immunomodulators. No difference in the primary endpoint, the proportion of patients who required a decrease in infliximab dosing interval or cessation of infliximab due to the loss of response or clinical relapse, was found between the two groups over a 24-month period of follow-up (24 [60\%] of 50 patients who continued immunomodulator vs 22 [55\%] of 40 patients who discontinued immunomodulator), suggesting that the continuation of immunomodulators was not superior to withdrawal. Endoscopic healing, defined by the absence of mucosal ulcers, was also similar in both groups (16 [64\%] of 25 in the continuation group vs 14 [61\%] of 23 in the discontinuation group), although combination therapy was associated with lower concentrations of C-reactive protein (CRP). ${ }^{29} \mathrm{~A}$ further open-label RCT, DIAMOND2,34 assessed thiopurine withdrawal from the treatment regimen of patients in steroid-free clinical remission for at least 6 months following combination therapy with adalimumab. Preliminary results report no difference in the primary endpoint of steroid-free remission at 52 weeks, or in a secondary endpoint of mucosal healing, suggesting no clear benefit in continuation of immunomodulators beyond 6 months of clinical remission. However, only a small number of patients $(n=50)$ were included, and the thiopurine dose was much lower than that commonly used in Europe. ${ }^{34}$

A subsequent systematic review has analysed relapse rates following immunomodulator (azathioprine) discontinuation from combination therapy in Crohn's disease. Overall, 27 (49\%) of 55 patients relapsed after immunomodulator withdrawal compared with 27 (48\%) of the 56 patients who continued immunomodulators (RR 1.02 [0.68-1.52]; $\mathrm{p}=0.92$ ). However, the quality of data was considered low because of high risk of bias for study blinding and small patient numbers; ${ }^{32}$ nevertheless, retrospective cohort studies have also suggested no difference in clinical outcome. 26,30 One observational study reported a cumulative relapse rate of $27 \%$ at a median follow-up of 14 months, ${ }^{27}$ and a second reported $38 \%$ at 29 months. ${ }^{25}$ The probability of relapse appears to increase substantially over time, with a third study reporting a relapse rate of $72-. \%$ at a median follow-up of 61.6 months. ${ }^{20}$ Finally, in a paediatric population no difference in relapse was found between those randomly assigned to either continue (33.3\%) or discontinue immunomodulators (35.9\%). ${ }^{23}$

Only a small amount of data exists regarding the relapse of patients with ulcerative colitis following immunomodulator discontinuation, but a large retrospective study reported a lower prevalence of relapse among patients who continued on combination therapy (12 [3\%] of 392) than among those receiving infliximab alone (33 [12\%] of 282; $p=0-049) .{ }^{24}$ Studies investigating immunomodulator withdrawal from combination therapy are summarised in table 2 . 
In summary, withdrawal of immunomodulators from combination therapy in Crohn's disease does not appear to increase relapse rate at up to 2 years of follow-up. However, longer prospective studies are required for both Crohn's disease and ulcerative colitis.

\section{The effect of immunomodulators withdrawal on the immunogenicity of biological therapy}

When considering the withdrawal of immunomodulators from combination therapy, the increased risk of biological immunogenicity must be acknowledged. The development of antidrug antibodies is of greatest concern in patients given anti-TNF therapy, with the prospective PANTS study 35 reporting overall rates of antibody formation, with associated undetectable drug concentrations at week 54 , to be $31.2 \%$ with infliximab and $12.3 \%$ with adalimumab. 35 Conversely, the gut selective $\alpha 4 \beta 7$ integrin antibody vedolizumab, and the interleukin $12 / 23$ p40 subunit antibody ustekinumab, are associated with much lower rates of antibody formation (1-4.1\% for vedolizumab and $0.4-2.9 \%$ for ustekinumab). ${ }^{36}$ In anti-TNF therapy, the development of anti-drug antibodies is strongly associated with lower trough concentrations, loss of response, and infusion reactions. . $^{37,38}$

Several studies have suggested immunomodulator continuation is associated with improved infliximab pharmacokinetics. Initial prospective work reported higher infliximab trough concentrations in patients who continued immunomodulator therapy. ${ }^{28}$ This association was confirmed in an RCT that found low or undetectable infliximab concentrations, with or without anti-drug antibodies, in $14.3 \%$ of those who continued azathioprine at a dose of $2-2.5 \mathrm{mg} / \mathrm{kg}$ per day, $14.8 \%$ of patients who continued with a halved azathioprine dose, and $43.3 \%$ of patients who stopped azathioprine. ${ }^{20}$ Maintaining concentrations of the azathioprine metabolite 6-TGN at more than $105 \mathrm{pmol} / 8 \times 10^{8}$ red blood cells was suggested to prevent low infliximab trough concentrations. A separate cross-sectional study found that 6-TGN concentrations correlated with those of infliximab, and patients with lower 6-TGN concentrations $\left(<125 \mathrm{pmol} / 8 \times 10^{8} \mathrm{red}\right.$ blood cells) were more likely to have antibodies to infliximab (odds ratio [OR] 13, 95\% CI 2.372.5; p <0.01). ${ }^{39} \mathrm{~A}$ further study reported that combination therapy resulted in a longer drug antibody free survival. ${ }^{40}$ The effect of immunomodulators on adalimumab trough concentrations is less clear, with the DIAMOND2 study ${ }^{34}$ reporting no difference at week 52 when the immunomodulator was discontinued after at least 6 months of combination therapy. Finally, results from the PANTS study ${ }^{35}$ have shown that concurrent immunomodulator use reduces the risk of immunogenicity for both infliximab (hazard ratio [HR] 0.39; $<<0.0001$ ) and adalimumab (HR 0.44; p<0.0001). As expected, immunogenicity was strongly associated with nonremission. 35

The concept of optimised monotherapy, based on proactive therapeutic drug monitoring for anti-TNF drugs, has emerged as an alternative to combination therapy. In a retrospective study of 149 patients with IBD (94 patients with Crohn's disease and 55 with ulcerative colitis), the less favourable pharmacokinetic profile initially observed with infliximab monotherapy could be overcome with dose escalation based on close therapeutic drug monitoring, with no difference in infliximab discontinuation, mucosal healing, hospitalisation, or long-term steroid use over a 
median follow-up of 19 months. ${ }^{41}$ Concordant results were reported in a second retrospective study, in which early infliximab dose escalation resulted in similar clinical outcomes and infliximab trough concentrations regardless of concurrent immuno- modulator. ${ }^{42}$

Taken together, although these data highlight the potential negative effect of immunomodulator withdrawal on anti-TNF pharmacokinetics and immunogenicity, an increased risk of relapse has not been shown, and proactive therapeutic drug monitoring emerges as a strategy to maintain anti-TNF efficacy.

\section{Withdrawal of anti-TNF therapy}

A number of studies over the past few years have focused on anti-TNF withdrawal both in patients with Crohn's disease and those with ulcerative colitis. ${ }^{43-47}$ Overall, most studies report a relapse rate of $40-50 \%$ over a 2-year period following discontinuation of the anti-TNF drug, but treatment with concurrent immunomodulators varies greatly between the studies. ${ }^{30,48}$ The STORI ${ }^{49}$ trial remains the only prospective study designed to assess prevalence of relapse after anti-TNF withdrawal, but it did not have a control group. The trial enrolled patients with Crohn's disease who had been treated for at least 1 year with infliximab and an antimetabolite, with steroid-free remission for a minimum of 6 months. The relapse rate was $43.9 \%$ (SE 5.0) at 12 months and 52.2\% (SE 5.2) at 24 months. ${ }^{49}$ Long-term outcomes, with a median follow-up of 7 years, have been published, with only $21.6 \%$ of patients remaining in remission, while $71 \%$ restarted biological therapy after a median of 13 months. Of the 64 patients who restarted biological treatment, 22 were treated unsuccessfully with infliximab, either as a result of major complications $(4 / 22)$ or secondary loss of response to infliximab (18/22) after a median time of 22 months. The cumulative incidence of unsuccessful infliximab treatment was $30.1 \%$ (95\% CI 18.5-42.5) 6 years after infliximab restart.50 Importantly, major complications occurred relatively late after infliximab withdrawal (median 45 months), including 14 surgeries and four complex perianal lesions, emphasising the importance of close long-term monitoring following de-escalation.

A retrospective cohort study compared the disease course of ulcerative colitis in clinical remission for at least 12 months in patients who continued or discontinued infliximab. Patients who discontinued infliximab had a higher probability of relapse (HR 3.41 [95\% CI 1.88-6.20]; $\mathrm{p}<0.001)$. A separate study reported the relapse rate in patients with ulcerative colitis to be $60 \%$ after 4.5 years of follow-up. ${ }^{43}$

A multicentre retrospective study assessed the risk of relapse both for patients with Crohn's disease and those with ulcerative colitis who discontinued anti-TNF after achieving clinical remission, with a median follow-up of 19 months. ${ }^{51}$ The cumulative incidence of relapse was 44\% per patient-year, with no significant difference between patients with Crohn's disease and those with ulcerative colitis. ${ }^{51} \mathrm{~A}$ large retrospective cohort study from the UK reported relapse after anti-TNF withdrawal in patients with Crohn's disease, ulcerative colitis, or IBD unclassified. ${ }^{46}$ Relapse rates were $36 \%$ at 1 year and $56 \%$ at 2 years of follow-up in patients with Crohn's disease compared with $42 \%$ at 1 year and $47 \%$ at 2 years in those with ulcerative colitis or IBD unclassified. The authors also did a meta-analysis, which supported their findings. ${ }^{46}$ The 
relapse rate at 1 year was 39\% (95\% CI 35-44) and 54\% (49-59) at 2 years for patients with Crohn's disease, whereas the relapse rate for patients with ulcerative colitis or IBD unclassified was $35 \%(26-43)$ at 1 year and $42 \%(27-58)$ at 2 years. ${ }^{46} \mathrm{~A}$ separate systematic review and meta-analysis produced similar results, with the overall risk of relapse after anti-TNF discontinuation being 44\% in patients with Crohn's disease and 38\% in those with ulcerative colitis. ${ }^{57}$ We have summarised the largest studies evaluating de-escalation from anti-TNF (table $3)$.

An important and feared consequence of relapse following biological withdrawal in ulcerative colitis is colectomy. A prospective observational study reported outcomes following infliximab discontinuation in 51 patients in clinical remission: 18 (35\%) patients needed to restart biological therapy, with only one patient not responding and requiring colectomy. ${ }^{54}$ Similarly, a separate study found that only one of 48 patients required colectomy following the withdrawal of infliximab. ${ }^{46}$ Additionally, a retrospective multinational cohort study of 193 patients found no differences in the frequency of colectomy between those who had discontinued infliximab and those who had continued on it. 58 To the best of our knowledge, no studies have evaluated the clinical outcomes after stopping other biological agents, such as vedolizumab.

\section{Strategies for de-escalation of therapy in IBD: a review of the current evidence}

Although the long-term probability of maintaining remission following de-escalation of therapy appears disappointingly low, a number of strategies have been proposed to minimise the risk of a clinically significant relapse.

\section{STRATEGY ONE: THE SELECTION OF SUITABLE CANDIDATES FOR DE- ESCALATION}

The identification of subgroups of patients who are at considerably lower risk of relapse following drug withdrawal might be possible. A number of studies have reported predictive factors for relapse, including a comprehensive systematic review that determined that the majority of predictive factors reflect known poor prognostic features, previous challenging disease course, and markers of active disease. ${ }^{30}$ However, no predictive factors for relapse have been consistently reproduced in ulcerative colitis, making stratification difficult in this cohort.

Both demographics and clinical history must be considered when contemplating de-escalation. Young age at diagnosis and male sex are poor prognostic features for both ulcerative colitis and Crohn's disease. ${ }^{30}$ However, of note, men younger than 35 years are at greatest risk of hepatosplenic T-cell lymphoma following more than 2 years of thiopurine therapy with or without anti-TNF, which although rare, carries a poor prognosis, underlining the challenges of decision making. ${ }^{59}$ Conversely, the risks of both infection and malignancy increase with thiopurine and anti-TNF treatment if the patient is older than 65 years, favouring discontinuation in older patients. ${ }^{10}$ Extensive disease is an important risk factor for Crohn's disease, which has also been proposed for ulcerative colitis; additional adverse clinical features 
of Crohn's disease include smoking, perianal or colonic disease, and stricturing disease. $30,47,51,55,60$ Discontinuation of biological therapy in perianal disease is associated with particularly high relapse rates, and continuation of therapy is strongly favoured in this group. ${ }^{61,62}$ Treatment history is also important, with a previous need for surgery, unsuccessful immunomodulator therapy, or relapsing course requiring escalation of therapy associated with higher risk of relapse. ${ }^{30,51}$

The consequences of disease progression must also be assessed as part of the decision-making process. For example, one might decide not to de-escalate in a patient considered at low risk of relapse who has had multiple previous bowel resections, because any disease recurrence would place them at high risk of short bowel syndrome.

Important laboratory markers of active disease that predict failure of de-escalation in Crohn's disease include elevated CRP and neutrophil or white cell count, low haemoglobin, and elevated faecal calprotectin. ${ }^{49,55}$ Subtle abnormalities might confer substantially increased risk, with a white cell count more than $6 \times 10^{9}$ cells per L, haemoglobin less than or equal to $14.5 \mathrm{~g} / \mathrm{L}$, and CRP greater than or equal to $5 \mathrm{mg} / \mathrm{L}$ associated with risk of relapse on withdrawal of anti-TNF in Crohn's disease. ${ }^{49,50}$ A model from the STORI trial, ${ }^{49}$ which incorporated these parameters, together with the additional variables of male sex, absence of surgical resection, and faecal calprotectin of $300 \mathrm{pg} / \mathrm{g}$ or greater, found that the presence of two or fewer risk factors was associated with a $15 \%$ relapse rate at 1 year.

Faecal calprotectin might be elevated in the absence of endoscopic disease activity, and can help identify patients in deep remission, with concentrations of less than $56 \mathrm{pg} / \mathrm{g}$ predictive of stable remission in both ulcerative colitis and Crohn's disease. ${ }^{63}$ In ulcerative colitis, a white cell count of more than $9.1 \times 10^{9}$ cells per L predicted relapse after withdrawal of azathioprine in one retrospective study, ${ }^{64}$ although this association has not been shown in other work. Evidence of mucosal healing at either imaging or endoscopy is associated with a reduced risk of relapse in patients with Crohn's disease, with histological grade predictive in ulcerative colitis in a single study. ${ }^{60,52,65}$

Importantly, up to $30 \%$ of patients with Crohn's disease considered to be in deep remission with mucosal healing and low faecal calprotectin will still relapse, highlighting the importance of additional factors, such as the microbiome. ${ }^{66,67} \mathrm{~A}$ subanalysis of the STORI trial suggested that a low abundance of Faecalibacterium prausnitzii (adjusted HR 4.1 [95\% CI 1.2-13.3]; p=0.014) and Bacteroides (3.3 [1.1-10.1]; $\mathrm{p}=0.030)$ predicted relapse following anti-TNF withdrawal independently of high CRP $(\mathrm{p}=0.0001){ }^{68}$

A review of recent drug concentrations might also guide de-escalation decisions. Low or undetectable infliximab trough concentrations appear helpful in predicting a reduced risk of relapse when the drug is withdrawn. ${ }^{49,52}$ Most probably, this observation simply reflects that clinical remission has been achieved in the absence of a therapeutic dose of infliximab. The same is likely to be true for adalimumab concentration, but data are scarce. Conversely, for patients on combined infliximab and immunomodulator therapy, a higher infliximab trough concentration predicts a lower relapse rate when the immunomodulator is withdrawn. ${ }^{27}$

Finally, of note, most of the predictive factors arise from retrospective studies, and thus a clear need exists for a well powered prospective study in this area. 


\section{STRATEGY TWO: DOSE DE-ESCALATION}

Dose reduction presents an alternative to complete drug withdrawal, providing cost savings and potentially reducing the risk of side-effects, although the reduction of side-effects has not yet been proven in patients with IBD. An increased risk of non-Hodgkin lymphoma was reported following higher doses of azathioprine in a large population of patients who had received a solid organ transplant, while higher concentrations of 6-TGN were associated with a higher risk of skin cancer in patients who had received renal transplants. ${ }^{69,70}$ Additionally, no data are available that prove a link between higher concentrations of biological agents and side-effects in IBD; however, an association between increasing drug concentration and increased risk of infection has been reported in patients with rheumatoid arthritis. ${ }^{71}$

As previously outlined, one RCT has found that reduction of azathioprine, but not withdrawal, in patients receiving combination therapy, maintained similar median infliximab trough concentrations to continuation at full dose, supporting a dose de-escalation strategy. ${ }^{21}$ The TAXIT trial ${ }^{14}$ showed that monitoring of infliximab trough concentrations leads to more efficient dosing and allows safe dose reduction. ${ }^{14}$ At a single tertiary health-care centre, only 115 (44\%) of263 patients with Crohn's disease and ulcerative colitis who were clinically stable on infliximab maintenance therapy had optimal trough concentrations of 3-7 pg/mL and concentrations of more than $7 \mathrm{pg} / \mathrm{mL}$ were observed in $27 \%$ of the group.

Importantly, patients randomly assigned to receive a dose regimen altered on the basis of serial monitoring of trough concentrations over a 1-year period had fewer flares than did those randomly assigned to be dosed on clinical criteria alone, although no difference in remission rate was noted. Two recent studies,72,73 further support the use of therapeutic drug monitoring to guide dose de-escalation. In a retrospective analysis of 91 patients with IBD receiving infliximab a trough concentration of more than $5-7 \mathrm{pg} / \mathrm{mL}$ before de-escalation and serial trough concentration of more than $2-4 \mathrm{pg} / \mathrm{mL}$ following de-escalation were associated with a lower risk of relapse. ${ }^{72}$ In a further retrospective study of 96 patients with IBD, dose de-escalation of infliximab if trough concentrations were more than $7 \mathrm{pg} / \mathrm{mL}$ was associated with a decreased risk of relapse (HR 0-45; $\mathrm{p}=0$-024) compared with clinical de-escalation. ${ }^{73}$

Lengthening of intervals between doses could also help achieve dose de-escalation. A retrospective study investigated the lengthening of dose intervals with adalimumab in patients with Crohn's disease. Adalimumab was de-escalated from every other week to every 3 weeks in patients with trough adalimumab concentrations of more than $7 \mathrm{pg} / \mathrm{mL}$ or side-effects or both. $26(65 \%)$ of 40 patients remained in clinical remission with trough adalimumab concentrations of more than $4 \mathrm{pg} / \mathrm{mL}$ for a median follow-up of 24 months. ${ }^{74}$ Importantly, dose de-escalation was associated with the resolution of side-effects in half the patients. A CRP of less than 3-5 $\mathrm{mg} / \mathrm{L}$ at time of de-escalation was the only independent predictor of sustained remission. Dose de-escalation of adalimumab from every week to every other week was assessed in a separate retrospective study in Crohn's disease, and was successful in $63 \%$ of patients. ${ }^{75}$

\section{STRATEGY THREE: EARLY DETECTION AND TREATMENT OF RELAPSE}

Careful objective monitoring for relapse is important following drug withdrawal because disease relapse might occur without clinical symptoms and both patients and health-care professionals might underestimate the relevance of mild symptoms. ${ }^{76}$ The risk of relapse is highest in the first 
year following drug withdrawal; therefore, more intensive monitoring is appropriate. ${ }^{60}$ Despite substantial variability, secondary analysis of the STORI trial showed a higher median CRP concentration among patients who relapsed, with a concentration of more than $5 \mathrm{mg} / \mathrm{L}$ associated with a HR for relapse of 4-2 (95\% CI 1-9-9-2; p<0-001).r7 Serial monitoring of faecal calprotectin is also of value in predicting relapse following withdrawal of anti-TNF, based on data from a prospective multicentre study ${ }^{78}$ of patients with both Crohn's disease and ulcerative colitis. ${ }^{78}$ Faecal calprotectin was found to increase up to 6 months before evidence of endoscopic relapse, with consistently low concentrations associated with sustained remission following drug withdrawal. Median concentrations consistently more than $120 \mathrm{pg} / \mathrm{g}$ were seen in patients who relapsed, which is substantially lower than the threshold of $250 \mathrm{pg} / \mathrm{g}$ reported as an independent predictor of relapse in the STORI trial (HR 6-5 [95\% CI 2-7-15-6]; p<0-001), but this outcome might reflect the observation that baseline concentrations were also significantly higher in the STORI trial.49,77

An important consideration following de-escalation is whether the patient's response can be safely recaptured in the event of a relapse. In a multicentre UK study, reintroduction of thiopurine following a previous treatment regimen with thiopurine-lasting a median duration of 6 years-was successful in 31 (74\%) of 42 patients with Crohn's disease and in 22 (92\%) of with ulcerative colitis. ${ }^{64}$ Two-thirds of patients with Crohn's disease and half of those with ulcerative colitis also required systemic steroids to reinduce remission. It is notable that 25 (86\%) of 29 patients with Crohn's disease and moderate-to-severe relapse within 12 months of azathioprine withdrawal required systemic steroids, anti-TNF, or hospital admission, with five of these patients requiring surgical resection. In an earlier study, remission was recaptured in 22 (96\%) of 23 patients with Crohn's disease in an earlier study, although alternative therapy was chosen in nine (28\%) of the 32 patients who initially relapsed following azathioprine withdrawal. ${ }^{31}$ Favourable proportions of patients who recaptured remission are also reported for anti-TNF therapy (table 4). A meta-analysis of retreatment with the same anti-TNF in 290 patients with IBD found the rate of recapture of remission to be $80 \%$ (95\% CI 68-91; $\mathrm{p}<0.00001$ ), with response rates similar for both Crohn's disease and ulcerative colitis. ${ }^{57}$ This rate is similar to that reported in two prospective studies, including the STORI trial. ${ }^{49,81}$ Higher early trough concentrations of infliximab upon reintroduction have been associated with longterm response.82 Continued use of immunomodulators during the period of anti-TNF drug withdrawal in most patients is likely to protect against immunogenicity that would lead to loss of response and infusion reactions when the drug is reintroduced. 60

Data from 2017 suggest promising rates of recapture of response and a much lower risk of immunogenicity with vedolizumab. ${ }^{83}$ Interim analysis of the GEMINI longterm safety study ${ }^{83}$ shows that remission rates improved from $9 \%$ to $48 \%$ at week 28 of retreatment for patients with Crohn's disease who withdrew early from the GEMINI2 placebo maintenance phase because of relapse or non-medical reasons.

Interest in the concept of drug holidays is growing, with the recognition that although therapies do not cure the underlying disease-meaning that relapse is common-the natural history of IBD is cyclical. Consequently, patients might experience long periods of remission after drug withdrawal once they have reached deep remission. ${ }^{17,49,84}$ Even transient drug withdrawal might be beneficial, reducing the total lifetime treatment burden and potentially reducing adverse 
events and cost. ${ }^{47}$ In cases of borderline pharmacokinetics and low adherence with biological therapy, temporary drug cessation might also be less immunogenic. ${ }^{84} \mathrm{As}$ retreatment appears safe and effective in the majority of patients, this approach shows considerable promise and is the subject of ongoing research. ${ }^{46,49,57,85}$

\section{CLINICIAN AND PATIENT PERSPECTIVES TO DE-ESCALATION}

When considering de-escalation, the views of both the clinicians and the patients must be taken into account. Two surveys published in $2017^{86}$ and $2018^{87}$ are particularly illuminating with regard to this aspect of management. The first study, from the BIOCYCLE group, ${ }^{86}$ reported that gastroenterologists were significantly more likely to stop immunomodulator use $(75 \%$ in Europe and $61 \%$ in the USA; $p=0.05$ ) than biological therapy $(23 \%$ in Europe and $29 \%$ in the USA) for patients in with Crohn's disease who are in remission. The risk of malignancy was regarded to be the most important reason for stopping immunomodulator therapy, with cost being the primary reason for stopping biological therapy. Importantly, there were clear cultural differences, with European gastroenterologists more likely than their US counterparts to recommend stopping combination therapy ( $44 \%$ in Europe vs $18 \%$ in the USA; $\mathrm{p}<0.05$ ). ${ }^{86}$

A second survey ${ }^{87}$ explored patient attitudes to de-escalation of combination therapy in Crohn's disease in both France and the USA. Substantially more patients preferred to stop the immunomodulator regimen (53\% in the USA vs $47 \%$ in France) than anti-TNF therapy (26\% in the USA vs $28 \%$ in France). Importantly, $26 \%$ of all patients would not accept any de-escalation if the process increased the risk of an acute flare, and $56 \%$ of all patients were more concerned by Crohn's disease activity than the risk of treatment-associated malignancy. Once again cultural differences were reported, with French patients more likely than US patients to consider stopping combination therapy if recommended by their clinician (69\% in France $v S 48 \%$ in the USA; $\mathrm{p}=0.04) .87$

\section{Current recommendations on the elective withdrawal of medical therapy for patients with IBD in remission}

In 2018, the European Crohn's and Colitis Organisation (ECCO) published guidance on treatment withdrawal in IBD. 60 The importance of individualising any withdrawal decision is emphasised, taking into account the views of the patient. When considering withdrawal of therapy, remission should be confirmed with a combination of clinical, biochemical, endoscopic, and imaging parameters, and predictors of relapse carefully considered.

For immunomodulator monotherapy, the ECCO guidance suggests that the risks and benefits of continued treatment should be discussed after 3-4 years for those in established remission. When used in combination, withdrawal of the immunomodulator is considered unlikely to increase relapse rates in Crohn's disease over the following 2 years, but this action might be inappropriate in patients with previously challenging disease or at high risk of unsuccessful biological treatment, including low infliximab trough concentrations. Anti-TNF withdrawal should typically only be considered in patients in deep remission, and maintenance 
immunomodulator therapy might be appropriate to reduce risk of relapse. Anti-TNF discontinuation is not recommended in patients with perianal fistula given the high risk of relapse. Monitoring with serial faecal calprotectin and CRP is advised following treatment withdrawal, together with reassessment with imaging and endoscopy. More intensive monitoring is recommended in the first year after withdrawal of anti-TNF given the high relapse rates. In the UK, the National Institute for Health and Care Excellence recommends that patients with IBD on anti-TNF therapy should be reassessed at least annually, with a trial of treatment withdrawal considered if the patient is in stable remission, but no further specific guidance on patient selection or subsequent monitoring is provided. 88,89

\section{A proposed withdrawal strategy}

The ECCO expert consensus provides valuable guidance for decision making. ${ }^{60}$ We agree that consideration of drug withdrawal should be made on a case-by-case basis and careful counselling of the patient is essential, including an explanation that the current predictors of outcome are not perfect. However, patients should also be reassured that they will be closely monitored following de-escalation, allowing early detection of relapse, and that clinical response will most likely be recaptured if therapy is restarted. Although the optimal frequency of monitoring has not been established, faecal calprotectin and CRP measurement every 3 months might be appropriate initially, allied with close observation of symptoms, recognising that the highest risk of relapse is in the first year. Following drug withdrawal any concern should prompt formal reassessment with endoscopy or imaging or both (figure). We emphasise the importance of carefully considering the consequences of relapse that might argue against de-escalation, even when risk of relapse is low.

\section{Future perspectives}

\section{UNMET RESEARCH NEEDS}

Much of the data on drug de-escalation is from retrospective studies; therefore, high-quality RCTs are needed to guide decision making, several of which are underway. The standard-of-care for moderate-to-severe Crohn's disease is combined therapy with an immunomodulator and biological therapy, but the SPARE study (NCT02177071), which forms part of the BIOCYCLE project, aims to definitively answer whether monotherapy is feasible. This multicentre European study will enrol 225 patients with Crohn's disease in stable remission to one of three groups: continuation of both immunomodulator and biological, continuation of only immunomodulator, or continuation of only biological therapy. The efficacy of each treatment group to maintain remission will be assessed. Further data on the discontinuation of infliximab in Crohn's disease will be provided by the STOP IT trial, ${ }^{90}$ while the BIOSTOP trial (EudraCT number 2016-00140918) will assess the effects of anti-TNF withdrawal in patients with ulcerative colitis and explore the feasibility of drug holidays, as the protocol allows for the anti-TNF to be restarted in the event of relapse. 


\section{Figure: An algorithm to guide decision making in drug de-escalation}

$\mathrm{CDAI}=$ Crohn's Disease Activity Index. $\mathrm{CDEIS}=$ Crohn's Disease Endoscopic Index of Severity. CRP=C-reactive protein. SES-CD=Simple Endoscopic Score for Crohn's Disease. SCAAI=Simple Clinical Colitis Activity Index.

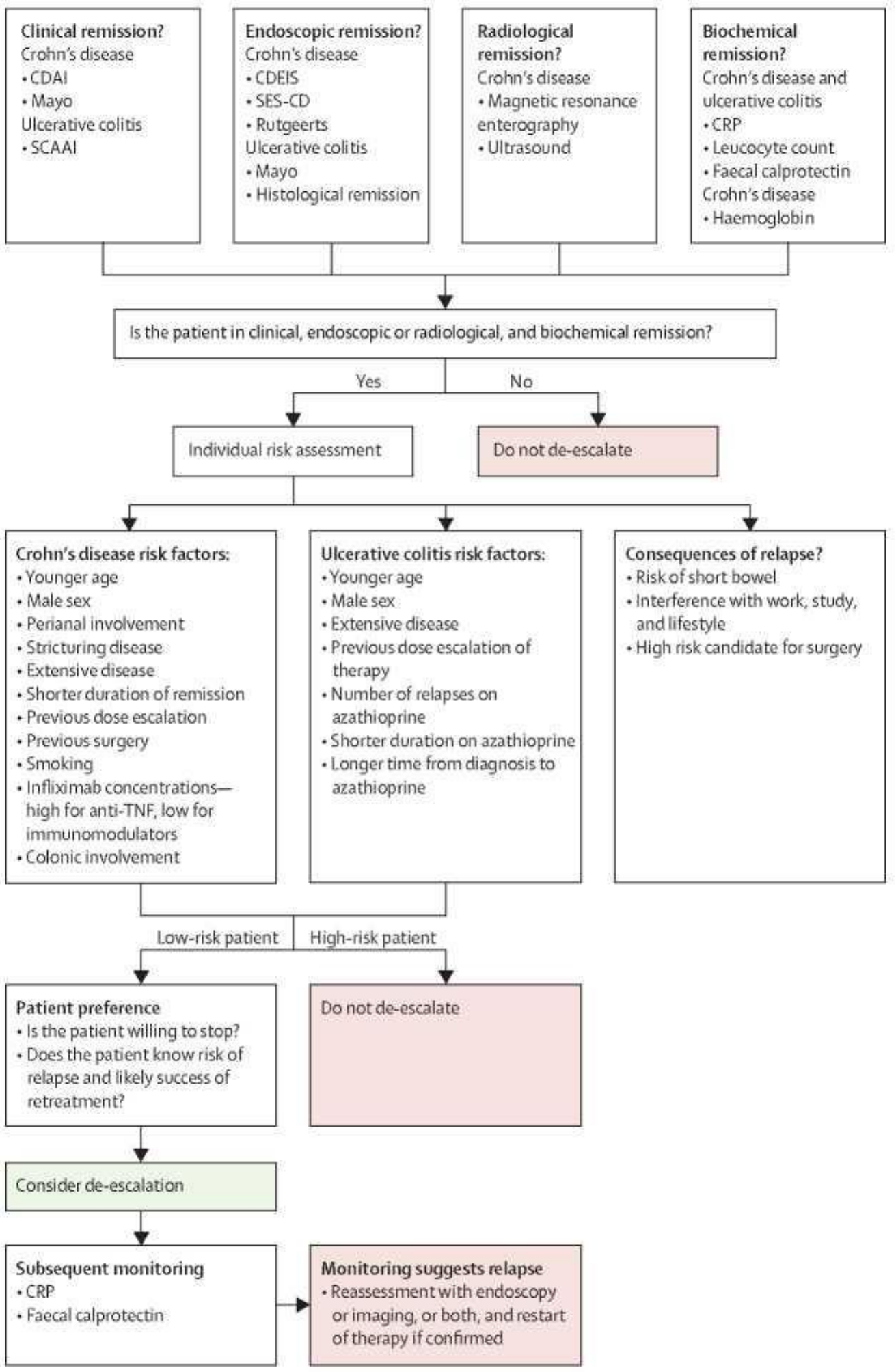




\section{PERSONALISATION OF APPROACH}

A core aim of the SPARE study is the identification of new biomarkers to predict the risk of relapse. This personalised approach to de-escalation of therapy is essential, as currently patients cannot be precisely stratified into appropriate treatment pathways. The use of molecular profiling to identify predictive biomarkers of disease course and treatment response is now of considerable research interest. In addition to HLA-DQA $1 * 05$, a number of other polymorphisms predict development of anti-drug antibodies, suggesting an additional benefit to determining a personalised gene expression signature for patients with IBD. ${ }^{35,91-93}$ Other genomics strategies are also under evaluation, including methylation, transcription, and protein glycosylation profiling. Additionally, the development of telemedicine systems promises closer monitoring of disease activity, and might enable earlier detection of relapse following treatment de-escalation in the future. ${ }^{94-97}$

\section{THE EFFECT OF EMERGING MEDICATIONS}

Novel therapies will probably substantially affect the clinician's approach to drug withdrawal. No data are available for relapse rates following withdrawal of newer biologicals, like vedolizumab and ustekinumab, but the low risk of immunogenicity to these agents might simplify drug cycling. The emergence of small molecule inhibitors, such as the JAK inhibitors tofacitinib and filgotinib, is very relevant. ${ }^{98}$ These agents pose no risk of immunogenicity and act rapidly, with data suggesting that drug holidays are highly feasible. Data from the OCTAVE trials $^{99}$ found that in patients who had previously responsed to tofacitinib, retreatment following a treatment interruption during the placebo phase of up to 44 weeks was effective in $75(76 \%)$ of 99 patients at 2 months.

\section{Search strategy and selection criteria}

We searched the PubMed database to identify relevant manuscripts from inception until March 31, 2019. The search combined the MeSH terms "inflammatory bowel disease", "Crohn's disease" and "ulcerative colitis" with the subheadings "de-escalation", "therapy withdrawal", "immunomodulator withdrawal", "biologic withdrawal", "dose reduction", "therapeutic drug monitoring", "drug holiday", "risk of relapse", "cost saving", "lymphoma", "severe infection", "opportunistic infection", and "patient preference". We also reviewed bibliographies of the included studies to identify additional important data. We also assessed recent guidelines and topical reviews. Only papers published in English were reviewed, with priority given to randomised clinical trials and meta-analyses. 


\section{Conclusion}

In summary, there remains much to learn about the appropriate and individualised deescalation of therapy in IBD. It is a highly important area in clinical practice, and worthy of greater research focus. With the emergence of stratified medicine, the next decade promises a potential transformation of both our understanding of IBD and the tools at our disposal, providing hope of greater precision in this challenging area of care

\section{CONTRIBUTORS}

JS, J-FC, and EL conceived the idea, TPC and CFG drafted the Review, and JS, J-FC, and EL made important revisions and intellectual contributions.

\section{DECLARATION OF INTERESTS}

EL reports funding from the European Union's Horizon 2020 research and innovation programme under grant agreement No 633168 - BIOCYCLE (PHC-13-2014); grants and personal fees; grants and personal fees from Abbvie, Takeda, Pfizer, and Janssen; and personal fees from Merck Sharp \& Dohme, Ferring, Falk, and Celgene, outside the submitted work. J-FC reports grants from Janssen and Takeda; work as a consultant or speaker for AbbVie, Amgen, Arena Pharmaceuticals, Boehringer- Ingelheim, Celgene, Celltrion, Eli Lilly, Enterome, Ferring Pharmaceuticals, Genentech, Janssen, Medimmune, Merck Sharp \& Dohme, Nextbiotix, Novartis Pharmaceuticals Corporation, Otsuka Pharmaceutical Development and Commercialization, Pfizer, Protagonist, Second Genome, Gilead, Seres Therapeutics, Shire, Takeda, and Theradiag; and holds stock options with Intestinal Biotech Development and Genfit (both outside the scope of this Review). JS reports funding from the European Union's Horizon 2020 research and innovation programme under grant agreement No 633168 - BIOCYCLE (PHC-13-2014); and personal fees from Takeda, outside the submitted work. TPC and CFG report no competing interests. 
Table 1: Randomised controlled trials of immunomodulator withdrawal

\begin{tabular}{|c|c|c|c|c|c|c|c|c|c|c|}
\hline & Participants & Definition of remission & Definition of relapse & Treatment & Relapse rate & & & & Time to & Notes \\
\hline & 0 & & & & 6 months & 12 months & 18 months & 24 months & & \\
\hline $\begin{array}{l}\text { Wenzl et al } \\
(2014)^{16}\end{array}$ & $\begin{array}{l}\text { Crohn's } \\
\text { disease } \\
(\mathrm{N}=52) ; \\
24 \text { months }\end{array}$ & $\begin{array}{l}\text { Clinical remission in } 12 \\
\text { months before enrolment, } \\
\text { and CDAI <150 at baseline; } \\
>4 \text { years azathioprine }\end{array}$ & $\begin{array}{l}\text { Clinical relapse (CDAI }>150 \\
\text { with an increase of } 60 \text {, new } \\
\text {; fistula development in a } \\
\text { patient without fistula at } \\
\text { enrolment; increase in PDAI by } \\
>4 \text {; hospitalisation for active } \\
\text { Crohn's disease; oral steroids } \\
\text { or anti-TN F or surgery) }\end{array}$ & $\begin{array}{l}\text { Placebo } \\
(\mathrm{n}=26) ; \\
\text { azathioprine } \\
(\mathrm{n}=26)\end{array}$ & $\begin{array}{l}\% \text { for } \\
\text { placebo; } \\
0 \% \text { for } \\
\text { azathioprine }\end{array}$ & $\begin{array}{l}23 \% \text { for } \\
\text { placebo; } 4 \% \\
\text { for } \\
\text { azathioprine }\end{array}$ & $\begin{array}{l}31 \% \text { for } \\
\text { placebo; } \\
12 \% \text { for } \\
\text { azathioprine }\end{array}$ & $\begin{array}{l}31 \% \text { for } \\
\text { placebo; } \\
15 \% \text { for } \\
\text { azathioprin } \\
\text { e }\end{array}$ & $\begin{array}{l}197 \text { months } \\
\text { for placebo; } \\
22-3 \text { months } \\
\text { for } \\
\text { azathioprine }\end{array}$ & \\
\hline $\begin{array}{l}\text { Lemann et al } \\
(2005)^{17}\end{array}$ & $\begin{array}{l}\text { Crohn's } \\
\text { disease } \\
(\mathrm{N}=83) ; \\
18 \text { months }\end{array}$ & $\begin{array}{l}\text { Clinical remission (CDAI } \\
<150 \text { )and no need for } \\
\text { medical or surgical } \\
\text { treatment in previous } 42 \\
\text { months; >3-5 years } \\
\text { azathioprine }\end{array}$ & $\begin{array}{l}\text { Clinical relapse } \\
\text { (CDAI > 250; CDAI 150-250 on } \\
3 \text { consecutive weeks with an } \\
\text { increase of 75; } \\
\text { need for surgery for Crohn's } \\
\text { disease [except limited } \\
\text { perianal disease]) }\end{array}$ & $\begin{array}{l}\text { Placebo } \\
(n=43) ; \\
\text { azathioprine } \\
(n=40)\end{array}$ & NA & $\begin{array}{l}16.5 \%(\mathrm{SE} \\
5.7) \text { for } \\
\text { placebo; NA } \\
\text { for } \\
\text { azathioprine }\end{array}$ & $\begin{array}{l}\text { 21-3\% (SE } \\
6.3 \text { ) for } \\
\text { placebo; } \\
7.9 \% \text { (SE } \\
\text { 4.4) for } \\
\text { azathioprine }\end{array}$ & NA & $\begin{array}{l}\text { 15-9 months } \\
\text { (SE0.9) for } \\
\text { placebo; } \\
\text { 17-3 months } \\
\text { (SE 0.5) for } \\
\text { azathioprine }\end{array}$ & $\begin{array}{l}\text { Non-inferiority } \\
\text { RCT; } \\
\text { azathioprine } \\
\text { withdrawal was } \\
\text { not equivalent to } \\
\text { continuation of } \\
\text { azathioprine } \\
\text { therapy in } \\
\text { maintaining } \\
\text { Crohn's disease } \\
\text { remission }\end{array}$ \\
\hline $\begin{array}{l}\text { Vilien at al } \\
(2004)^{18}\end{array}$ & $\begin{array}{l}\text { Crohn's } \\
\text { disease } \\
(\mathrm{N}=29) ;{ }^{*} 12 \\
\text { months }\end{array}$ & $\begin{array}{l}\text { Clinical remission }>2 \text { years } \\
\text { azathioprine }\end{array}$ & $\begin{array}{l}\text { Clinical relapse (CDAI }>150 \text {, } \\
\text { CDAI rise by }>75 \text {, or disease } \\
\text { activity requiring } \\
\text { intervention) }\end{array}$ & $\begin{array}{l}\text { Discontinuation } \\
(\mathrm{n}=15) ; \\
\text { continuation } \\
(\mathrm{n}=13)\end{array}$ & NA & $\begin{array}{l}53 \% \text { for } \\
\text { discontinuat } \\
\text { ion; } \\
15 \% \text { for } \\
\text { continuation }\end{array}$ & NA & NA & NA & $\begin{array}{l}\text { Not placebo } \\
\text { controlled }\end{array}$ \\
\hline
\end{tabular}




\begin{tabular}{|c|c|c|c|c|c|c|c|c|c|}
\hline $\begin{array}{l}\text { Hawthorne et } \\
\text { al (1992) }\end{array}$ & $\begin{array}{l}\text { Ulcerative } \\
\text { colitis } \\
(\mathrm{n}=67) ; \\
12 \text { months }\end{array}$ & $\begin{array}{l}\text { Steroid free clinical } \\
\text { remission and Baron 0-1 } \\
>6 \text { months azathioprine }\end{array}$ & Clinical or endoscopic relapse & $\begin{array}{l}\text { Placebo } \\
(\mathrm{n}=34) \\
\text { azathioprine } \\
(\mathrm{n}=33)\end{array}$ & $\mathrm{NA}$ & $\begin{array}{l}59 \% \text { for NA } \\
\text { placebo; } \\
36 \% \text { for } \\
\text { azathioprine }\end{array}$ & NA & NA & $\begin{array}{l}\text { Results from the } \\
\text { longterm } \\
\text { remission } \\
\text { patients: } 61 \% \text { for } \\
\text { placebo vs } 31 \% \text { for } \\
\text { azathioprine }\end{array}$ \\
\hline $\begin{array}{l}\text { O'Donoghue } \\
\text { et al }(1978)^{20}\end{array}$ & $\begin{array}{l}\text { Crohn's } \\
\text { disease } \\
(\mathrm{N}=51) ; \\
12 \text { months }\end{array}$ & $\begin{array}{l}\text { Clinical remission }>6 \\
\text { months azathioprine }\end{array}$ & Clinical relapse & $\begin{array}{l}\text { Placebo } \\
(n=24) ; \\
\text { azathioprine } \\
(n=27)\end{array}$ & $\begin{array}{l}25 \% \text { for } \\
\text { placebo; } \\
0 \% \text { for } \\
\text { azathioprine }\end{array}$ & $\begin{array}{l}33 \% \text { for NA } \\
\text { placebo; } 4 \% \\
\text { for } \\
\text { azathioprine }\end{array}$ & NA & NA & $\begin{array}{l}\text { Low dose steroids } \\
\text { allowed in } \\
\text { definition of stable } \\
\text { disease }\end{array}$ \\
\hline
\end{tabular}

Table2: Studies of immunomodulator withdrawal from combination therapy

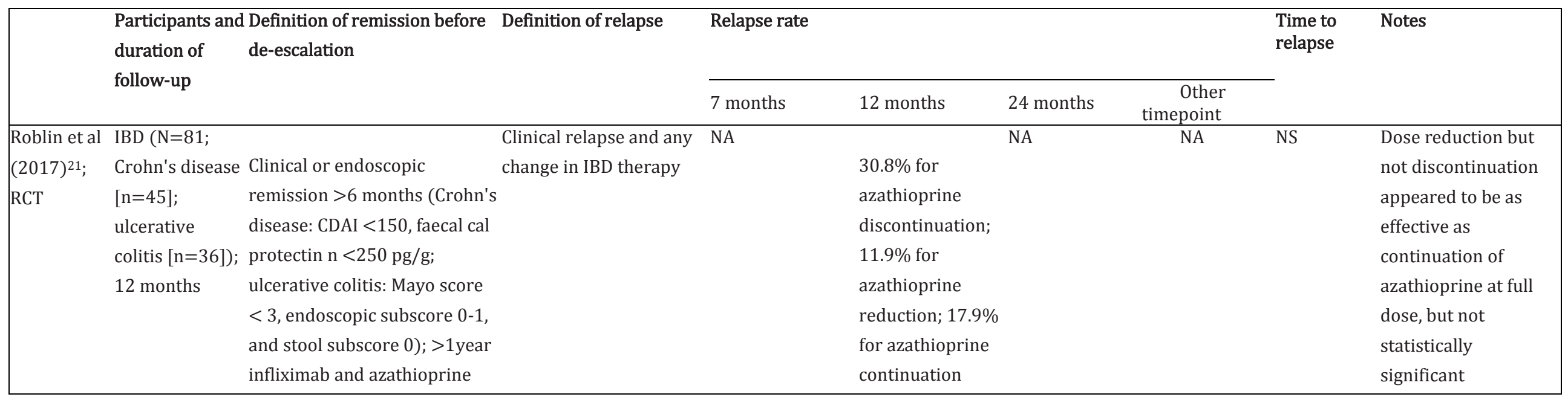




\begin{tabular}{|c|c|c|c|c|c|c|c|c|c|}
\hline $\begin{array}{l}\text { Fischer et al } \\
(2017)^{22} ; \\
\text { retrospectiv } \\
\text { e }\end{array}$ & $\begin{array}{l}\text { Crohn's disease } \\
(\mathrm{N}=43) ; \\
\text { median } 62.5 \\
\text { months }\end{array}$ & $\begin{array}{l}\text { Clinical remission }>5-4 \\
\text { months; }>4 \text { months infliximab } \\
\text { and immunomodulators }\end{array}$ & $\begin{array}{l}\text { Clinical relapse and the } \\
\text { need for steroids, anti- } \\
\text { TNF switch, } \\
\text { hospitalisation, or } \\
\text { retreatment with } \\
\text { immunomodulators }\end{array}$ & & NA & NA & $\begin{array}{l}\text { At end of } \\
\text { follow-up } 72- \\
1 \% \text { for the } \\
\text { discontinuation } \\
\text { group }\end{array}$ & $\begin{array}{l}\text { Median } 28.1 \\
\text { months }\end{array}$ & $\begin{array}{l}\text { No difference was } \\
\text { found between those } \\
\text { who stopped or de- } \\
\text { escalated therapy in } \\
\text { terms of the length of } \\
\text { time to relapse }\end{array}$ \\
\hline $\begin{array}{l}\text { Kierkusetal } \\
(2015)^{23} ; \\
\text { RCT }\end{array}$ & $\begin{array}{l}\text { Crohn's disease } \\
(\mathrm{N}=84) ; \\
7 \text { months }\end{array}$ & $\begin{array}{l}\text { Clinical remission }>4 \text { months } \\
\text { (PCDAI <30 and PCDAI drop } \\
>15 \text { since infliximab started); } \\
>6.5 \text { months infliximab and } \\
\text { azathioprine }\end{array}$ & $\begin{array}{l}\text { Clinical relapse or loss of } \\
\text { response to anti -TN F }\end{array}$ & $\begin{array}{l}35.9 \% \text { for the } \\
\text { discontinuation } \\
\text { group; } 33.3 \% \text { for } \\
\text { the continuation } \\
\text { group }\end{array}$ & NA & NA & NA & NS & $\begin{array}{l}\text { High risk of bias: no } \\
\text { placebo and no } \\
\text { blinding }\end{array}$ \\
\hline $\begin{array}{l}\text { Filippi et al } \\
(2015)^{24} ; \\
\text { retrospectiv } \\
\text { e }\end{array}$ & $\begin{array}{l}\text { Ulcerative } \\
\text { colitis ( } \mathrm{N}=82) \text {; } \\
\text { median } 22.3 \\
\text { months (SD14 } \\
\text { months) }\end{array}$ & $\begin{array}{l}\text { Clinical remission }>6 \text { months } \\
\text { infliximab and azathioprine }\end{array}$ & $\begin{array}{l}\text { Clinical relapse requiring } \\
\text { a change of treatment, } \\
\text { unsuccessful inflixiab } \\
\text { regimen, or colectomy }\end{array}$ & NA & NA & NA & $\begin{array}{l}12 \% \text { by } \\
\text { trimester for } \\
\text { the } \\
\text { discontinuation } \\
\text { group; } 3 \% \text { for } \\
\text { the } \\
\text { continuation } \\
\text { group }\end{array}$ & $\begin{array}{l}\text { Mean } 7 \\
\text { months for } \\
\text { the } \\
\text { discontinuat } \\
\text { ion group; } \\
\text { mean } 16.6 \\
\text { months for } \\
\text { the contin- } \\
\text { uation } \\
\text { group }\end{array}$ & 更 \\
\hline $\begin{array}{l}\text { Drobne et al } \\
(2015)^{25} ; \\
\text { retrospectiv } \\
\text { e }\end{array}$ & $\begin{array}{l}\text { Crohn's disease } \\
(\mathrm{n}=117) ; \\
\text { median } 29 \\
\text { months }\end{array}$ & $\begin{array}{l}\text { Clinical and biochemical } \\
\text { remission }>6 \text { months (low } \\
\text { CRP }[<10 \mathrm{mg} / \mathrm{L}] \text {, persistent } \\
\text { improvement of IBD } \\
\text { symptoms) }>6-5 \text { months } \\
\text { infliximab and } \\
\text { immunomodulators }\end{array}$ & $\begin{array}{l}\text { Clinical and biochemical } \\
\text { relapse }\end{array}$ & NA & NA & NA & $\begin{array}{l}\text { At end of } \\
\text { follow-up 38\% } \\
\text { for the discon- } \\
\text { tinuation group }\end{array}$ & $\begin{array}{l}\text { Median time } \\
\text { to infliximab } \\
\text { dose } \\
\text { escalation } \\
42.9 \text { months }\end{array}$ & None \\
\hline
\end{tabular}




\begin{tabular}{|c|c|c|c|c|c|c|c|c|}
\hline $\begin{array}{l}\text { Choi et al } \\
(2010)^{26} ; \\
\text { retrospectiv } \\
\text { e }\end{array}$ & $\begin{array}{l}\text { Crohn's disease } \\
(\mathrm{N}=22) ; \\
12 \text { months } \\
\text { (mean or } \\
\text { median not } \\
\text { specified) }\end{array}$ & $\begin{array}{l}\text { Controlled disease for } 2 \\
\text { months infliximab, NS } \\
\text { azathioprine }\end{array}$ & $\begin{array}{l}\text { Recurrence requiring } \\
\text { steroids or surgery }\end{array}$ & $\begin{array}{l}42.8 \% \text { for the } \\
\text { discontinuation } \\
\text { group; } 40 \% \text { for } \\
\text { the continuation } \\
\text { group }\end{array}$ & NA & NA & NS & $\begin{array}{l}\text { No information on } \\
\text { definition of } \\
\text { remission }\end{array}$ \\
\hline $\begin{array}{l}\text { Oussalah et } \\
\text { al (2010)27; } \\
\text { retrospectiv } \\
\text { e }\end{array}$ & $\begin{array}{l}\text { Crohn's disease } \\
(\mathrm{N}=48) ; \\
\text { median } 14 \\
\text { months }\end{array}$ & $\begin{array}{l}\text { Clinical remission (CDAI } \\
<150) ;>6 \text { months infliximab } \\
\text { and azathioprine }\end{array}$ & $\begin{array}{l}\text { Infliximab failure, NA } \\
\text { intensification of dosing } \\
\text { or switch to adalimumab, } \\
\text { infliximab intolerance, or } \\
\text { major surgery }\end{array}$ & $\begin{array}{l}15 \% \text { for the } \\
\text { discontinuation } \\
\text { group }\end{array}$ & $\begin{array}{l}59 \% \text { for the } \\
\text { discontinuation } \\
\text { group }\end{array}$ & $\begin{array}{l}\text { At end of } \\
\text { follow-up } 27 \% \\
\text { for the discon- } \\
\text { tinuation group }\end{array}$ & $\begin{array}{l}\text { Median time } \\
\text { before } \\
\text { infliximab } \\
\text { failure } 23 \\
\text { months }\end{array}$ & $\begin{array}{l}\text { Duration of } \\
\text { combination therapy } \\
<27 \text { months } \\
\text { predictive of } \\
\text { infliximab failure on } \\
\text { azathioprine } \\
\text { withdrawal }\end{array}$ \\
\hline $\begin{array}{l}\text { Sokol et al } \\
(2009) 28 ; \\
\text { retrospectiv } \\
\text { e (abstract) }\end{array}$ & $\begin{array}{l}\text { IBD }(\mathrm{N}=118) \text {; } \\
\text { NS }\end{array}$ & $\begin{array}{l}\text { Controlled disease duration } \\
\text { before drug therapy N S }\end{array}$ & $\begin{array}{l}\text { Intensification of } \\
\text { infliximab dosing }\end{array}$ & $\begin{array}{l}38 \text { '8\% for the } \\
\text { discontinuation } \\
\text { group; } 40 \text { '6\% for } \\
\text { the continuation } \\
\text { group }\end{array}$ & NA & NA & NS & None \\
\hline $\begin{array}{l}\text { Van Assche } \\
\text { et al } \\
(2008) 29 ; \\
\text { RCT }\end{array}$ & $\begin{array}{l}\text { Crohn's disease } \\
(\mathrm{N}=80) ; \\
24 \text { months }\end{array}$ & $\begin{array}{l}\text { Clinical remission (absence of } \\
\text { intestinal or extra-intestinal } \\
\text { symptoms); }>6 \text { months } \\
\text { infliximab and } \\
\text { immunomodulators }\end{array}$ & $\begin{array}{l}\text { Clinical relapse (CDAI NA } \\
\text { increase by }>70 \text { leading } \\
\text { to change in infliximab } \\
\text { dosing or infliximab } \\
\text { stopped for any reason) }\end{array}$ & NA & $\begin{array}{l}55 \% \text { for the } \\
\text { discontinuation } \\
\text { group; } 60 \% \text { for } \\
\text { the } \\
\text { continuation } \\
\text { group }\end{array}$ & NA & NS & $\begin{array}{l}\text { No placebo and no } \\
\text { blinding }\end{array}$ \\
\hline
\end{tabular}

RCT=randomised controlled trial. IBD=inflammatory bowel disease. CDAI=Crohn's Disease Activity Index. NA=not applicable. NS=not specified. CRP=C-reactive protein. PCDAI=Paediatric Crohn's Disease Activity Index. Unless otherwise specified the duration of follow-up was the same at the duration of the RCT and is the same for all participants.

Table 3: Studies of withdrawal of biological therapy 


\begin{tabular}{|c|c|c|c|c|c|c|c|c|c|c|}
\hline & \multirow{2}{*}{$\begin{array}{l}\text { Participantsand } \\
\text { duration of } \\
\text { follow-up }\end{array}$} & \multirow{2}{*}{$\begin{array}{l}\text { Proportion } \\
\text { given immuno } \\
\text { modulators } \\
(\%)\end{array}$} & \multirow{2}{*}{$\begin{array}{l}\text { Definition of } \\
\text { remission before de- } \\
\text { escalation }\end{array}$} & \multicolumn{4}{|c|}{ Definition of relapse Relapse rate } & \multirow{2}{*}{$\begin{array}{l}\text { Long-term } \\
\text { outcome }\end{array}$} & \multirow{2}{*}{$\begin{array}{l}\text { Time to } \\
\text { relapse }\end{array}$} & \multirow[t]{2}{*}{ Notes } \\
\hline & & & & & 6 months & 12 months & 24 months & & & \\
\hline $\begin{array}{l}\text { Casanova et al } \\
(2017)^{51} ; \\
\text { retrospective }\end{array}$ & $\begin{array}{l}\text { IBD (N=1055; } \\
\text { Crohn's disease } \\
{[\mathrm{n}=731] ;} \\
\text { ulcerative colitis } \\
[\mathrm{n}=324]) ; \\
\text { median } 19 \\
\text { months (>6 } \\
\text { months) }\end{array}$ & $\begin{array}{l}\text { 68\% (after } \\
\text { biological } \\
\text { withdrawal) }\end{array}$ & $\begin{array}{l}\text { Clinical remission } \\
\text { (luminal Crohn's } \\
\text { disease: Harvey- } \\
\text { Bradshaw Index } \leq 4 \text {; } \\
\text { perianal Crohn's } \\
\text { disease: absence of } \\
\text { fistula drainage } \\
\text { ulcerative colitis: } \\
\text { partial Mayo score } \\
\leq 2 \text { ) duration before } \\
\text { drug therapy NS }\end{array}$ & $\begin{array}{l}\text { Clinical, } \\
\text { biochemical, } \\
\text { endoscopic, or } \\
\text { radiological activity } \\
\text { leading to } \\
\text { therapeutic } \\
\text { intervention } \\
\text { (medical or } \\
\text { surgery) }\end{array}$ & $\begin{array}{l}15 \% \text { for the } \\
\text { discontinuat } \\
\text { ion } \\
\text { group }\end{array}$ & $24 \%$ & $38 \%$ & $\begin{array}{l}46 \% \text { relapse } \\
\text { at } 3 \text { years; } \\
56 \% \text { at } 5 \\
\text { years }\end{array}$ & $\begin{array}{l}\text { Median time } \\
11 \text { months } \\
\text { (range: } 1- \\
140 \text { ) }\end{array}$ & $\begin{array}{l}\text { The IBD subtype was not } \\
\text { associated with risk of } \\
\text { relapse; in patients classified } \\
\text { as being in deep remission, } \\
\text { the rate of re lapse was still } \\
\text { similar ( } 22 \% \text { for Crohn's } \\
\text { disease and } 20 \% \text { for } \\
\text { ulcerative colitis after } 1 \\
\text { year) }\end{array}$ \\
\hline $\begin{array}{l}\text { Reenaers et al } \\
(2018)^{50} ; \\
\text { retrospective }\end{array}$ & $\begin{array}{l}\text { Crohn's disease } \\
(\mathrm{N}=102) ; \text { mediar } \\
83 \text { months }\end{array}$ & $\begin{array}{l}\text { 100\% (after } \\
\text { biological } \\
\text { withdrawal) }\end{array}$ & $\begin{array}{l}\text { Clinical remission } \\
(\mathrm{CDAI}<150)>12 \\
\text { months infliximab } \\
\text { and } \\
\text { immunomodulators }\end{array}$ & $\begin{array}{l}\text { Need to restart } \\
\text { biological, major } \\
\text { complications } \\
\text { (surgery, complex } \\
\text { perianal lesions)_- } \\
\text { so called infliximab } \\
\text { failure }\end{array}$ & NA & NA & NA & $\begin{array}{l}78-4 \% \\
\text { restarted } \\
\text { biological or } \\
\text { had major } \\
\text { complications } \\
\text { and 34\% had } \\
\text { infliximab } \\
\text { failure }\end{array}$ & $\begin{array}{l}\text { Median time } \\
\text { to infliximab } \\
\text { retreatment: } \\
13 \text { months }\end{array}$ & $\begin{array}{l}\text { Two-thirds of patients were } \\
\text { successfully deescalated, a } \\
\text { fifth of patients never } \\
\text { restarted biological therapy }\end{array}$ \\
\hline $\begin{array}{l}\text { Kennedy et al } \\
(2016)^{46} ; \\
\text { retrospective }\end{array}$ & $\begin{array}{l}\text { IBD }(\mathrm{N}=166 ; \\
\text { Crohn's disease } \\
\text { [n=146; median } \\
\text { follow-up } 24 \\
\text { months]; } \\
\text { ulcerative colitis } \\
\text { or IBD } \\
\text { unclassified }\end{array}$ & $\begin{array}{l}66.3 \% \text { with } \\
\text { IBD: } 66 \% \text { with } \\
\text { Crohn's disease } \\
\text { and } 75 \% \text { with } \\
\text { ulcerative } \\
\text { colitis }\end{array}$ & $\begin{array}{l}\text { Steroid free clinical } \\
\text { remission }>6 \\
\text { months, }>12 \text { months } \\
\text { anti- TN F with or } \\
\text { without } \\
\text { immunomodulators }\end{array}$ & $\begin{array}{l}\text { Need for steroids, } \\
\text { surgery, } \\
\text { retreatment with } \\
\text { biological, } \\
\text { hospitalisation, or } \\
\text { immunomodulators }\end{array}$ & NA & $\begin{array}{l}36.2 \% \text { for } \\
\text { Crohn's } \\
\text { disease; } 41 \text { - } \\
8 \% \text { for } \\
\text { ulcerative } \\
\text { colitis }\end{array}$ & $\begin{array}{l}55.7 \% \text { for } \\
\text { Crohn's } \\
\text { disease; } \\
47.1 \% \text { for } \\
\text { ulcerative } \\
\text { colitis }\end{array}$ & $\begin{array}{l}\text { At end of } \\
\text { follow-up 51- } \\
3 \% \text { of } \\
\text { patients with } \\
\text { Crohn's } \\
\text { disease } \\
\text { relapse; } 45 \% \\
\text { for ulcerative }\end{array}$ & NS & $\begin{array}{l}\text { Approximately a third of } \\
\text { patients with IBD flared } \\
\text { within } 12 \text { months of } \\
\text { withdrawal of anti- TNF }\end{array}$ \\
\hline
\end{tabular}




\begin{tabular}{|c|c|c|c|c|c|c|c|c|}
\hline & $\begin{array}{l}{[\mathrm{n}=20 \text {; [median }} \\
\text { follow-up } 23 \\
\text { months]) }\end{array}$ & & & & & colitis & & \\
\hline $\begin{array}{l}\text { Papamichael et } \\
\text { al }(2015)^{52} ; \\
\text { retrospective }\end{array}$ & $\begin{array}{l}\text { Crohn's disease } \\
(\mathrm{N}=100) ; \text { median } \\
9.7 \text { years }\end{array}$ & $84 \%$ & $\begin{array}{l}\text { Clinical remission } \\
\text { (PGA); with median } \\
\text { infliximab } 73 \text { months } \\
\text { (IQR 1.4-16.2 } \\
\text { months) }\end{array}$ & $\begin{array}{l}\text { Need for steroids, NA } \\
\text { surgery or } \\
\text { retreatment with } \\
\text { anti-TNF, } \\
\text { retreatment or } \\
\text { need for thiopurine }\end{array}$ & $\begin{array}{ll}\% \text { for the } & 7 \% \text { for the } \\
\text { discontinua discontinuat } \\
\text { tion } & \text { ion } \\
\text { group } & \text { group } \\
& \\
& \end{array}$ & $\begin{array}{l}12 \% \text { of } \\
\text { patients } \\
\text { relapsed at } \\
3 \text { years, } 27 \text { - } \\
2 \% \text { at } 5 \text { years, } \\
\text { and } 48 \% \text { at } \\
\text { end of follow- } \\
\text { up }\end{array}$ & NS & $\begin{array}{l}\text { Lowest rates of relapse } \\
\text { reported; many patients } \\
\text { included were treated } \\
\text { episodically }\end{array}$ \\
\hline $\begin{array}{l}\text { Dai et al } \\
(2014)^{53} ; \\
\text { prospective }\end{array}$ & $\begin{array}{l}\text { IBD }(\mathrm{N}=216 ; \\
\text { Crohn's disease } \\
\text { [n=109]; } \\
\text { ulcerative colitis } \\
\text { or IBD } \\
\text { unclassified } \\
\text { [n=107]); } \\
12 \text { months }\end{array}$ & $\begin{array}{l}\text { 30-6\% with } \\
\text { IBD: } 41 \% \text { with } \\
\text { Crohn's disease } \\
\text { and } 20 \% \text { with } \\
\text { ulcerative } \\
\text { colitis }\end{array}$ & $\begin{array}{l}\text { Clinical remission } \\
\text { duration before drug } \\
\text { therapy NS }\end{array}$ & $\begin{array}{l}\text { Clinical relapse } \\
\text { (Crohn's disease: } \\
\text { CDAI rise of }>100 \\
\text { and CDAI >150; } \\
\text { ulcerative colitis: } \\
\text { partial Mayo }>3 \text { ) }\end{array}$ & $\begin{array}{l}21.1 \% \text { for NA } \\
\text { Crohn's } \\
\text { disease; } \\
14 \% \text { for } \\
\text { ulcerative } \\
\text { colitis }\end{array}$ & $\mathrm{NA}$ & $\begin{array}{l}\text { Median time: } \\
4.8 \text { months } \\
\text { for Crohn's } \\
\text { disease and } \\
67 \text { months for } \\
\text { ulcerative } \\
\text { colitis }\end{array}$ & NA \\
\hline $\begin{array}{l}\text { Farkas et al } \\
(2014)^{54} ; \\
\text { prospective }\end{array}$ & $\begin{array}{l}\text { IBD }(\mathrm{N}=47 ; \\
\text { Crohn's disease } \\
{[\mathrm{n}=35] ;} \\
\text { ulcerative } \\
\text { colitis }[\mathrm{n}=12]) ; \\
12 \text { months }\end{array}$ & $81 \%$ & $\begin{array}{l}\text { Clinical remission } \\
\text { (Crohn's disease: } \\
\text { CDAI <150 ulcerative } \\
\text { colitis: Mayo <2) } \\
>12 \text { months } \\
\text { infliximab or } \\
\text { adalimumab with or } \\
\text { without }\end{array}$ & $\begin{array}{l}\text { Clinical relapse } \\
\text { (Crohn's disease: } \\
\text { e CDAI rise of }>100 \\
\text { and } \\
\text { CDAI >150 points } \\
\text { ulcerative colitis: } \\
\text { partial Mayo }>3 \text { ) }\end{array}$ & $\begin{array}{l}61.7 \% \text { for NA } \\
\text { the } \\
\text { discontinua } \\
\text { tion } \\
\text { group }\end{array}$ & NA & NS & $\begin{array}{l}\text { Relapse rate combined for } \\
\text { ulcerative colitis and Crohn's } \\
\text { disease }\end{array}$ \\
\hline
\end{tabular}




\begin{tabular}{|c|c|c|c|c|c|c|}
\hline & & immunomodulators & & & & \\
\hline $\begin{array}{l}\text { Chauvin et al } \\
(2014)^{55} ; \\
\text { prospective }\end{array}$ & $\begin{array}{l}\text { Crohn's disease } 100 \% \\
(\mathrm{~N}=92) ; \text { median } \\
384 \text { months for } \\
\text { the maintenance } \\
\text { group; median } 55 \\
\text { months for the } \\
\text { induction group }\end{array}$ & $\begin{array}{l}\text { Clinical remission } \\
\text { (Harvey- Brad shaw } \\
\text { Index <4): } \\
\text { maintenance group } \\
\geq 1 \text { year infliximab } \\
\text { and immuno- } \\
\text { modulators; } \\
\text { induction group >8 } \\
\text { weeks infliximab and } \\
\text { immunomodulators }\end{array}$ & Clinical relapse & $\begin{array}{l}\qquad 4 \% \text { for } 64 \% \text { for the NA } \\
\text { the } \quad \text { maintenance } \\
\text { maintenance group; } 40 \% \\
\text { group; } 22 \% \text { for the } \\
\text { for the } \quad \text { induction } \\
\text { induction } \quad \text { group } \\
\text { group }\end{array}$ & $\begin{array}{l}\text { Median time } \\
15.9 \text { months } \\
\text { for the main- } \\
\text { tenance } \\
\text { group; } 327 \\
\text { months for } \\
\text { the induction } \\
\text { group }\end{array}$ & $\begin{array}{l}\text { Compared relapse rate after } \\
\text { two different infliximab } \\
\text { treatment strategies: } \\
\text { induction or maintenance for } \\
\text { at least } 1 \text { year }\end{array}$ \\
\hline $\begin{array}{l}\text { Molnar et al } \\
(2013)^{56} ; \\
\text { prospective }\end{array}$ & $\begin{array}{l}\text { Crohn's disease } \quad 83^{\prime} 6 \% \\
(\mathrm{~N}=121) ; \\
12 \text { months }\end{array}$ & $\begin{array}{l}\text { Clinical remission } \\
(\mathrm{CDAI}<150) \\
>52 \text { weeks infliximab } \\
\text { or adalimumab with } \\
\text { or without } \\
\text { immunomodulators } \\
\end{array}$ & $\begin{array}{l}\text { Clinical relapse } \\
(\text { CDAI rise }>100 \\
\text { and } C D A I>150)\end{array}$ & $\begin{array}{l}\text { he } 45 \% \text { fort NA } \\
\text { discontinuati } \\
\text { on } \\
\text { group }\end{array}$ & $\begin{array}{l}\text { Median time } \\
6 \text { months }\end{array}$ & $\begin{array}{l}\text { Biological therapy was } \\
\text { restarted a median of } 6 \\
\text { months after anti- TNF } \\
\text { discontinuation in almost } \\
\text { half of patients with Crohn's } \\
\text { disease } \\
\end{array}$ \\
\hline $\begin{array}{l}\text { Louis et al } \\
(2012)^{49} ; \\
\text { prospective }\end{array}$ & $\begin{array}{l}\text { Crohn's disease } 100 \% \\
(\mathrm{~N}=115) ; \\
\text { median } 12 \\
\text { months }\end{array}$ & $\begin{array}{l}\text { Steroid-free } \\
\text { remission }(>6 \\
\text { months); }>12 \\
\text { months infliximab } \\
\text { and } \\
\text { immunomodulators }\end{array}$ & $\begin{array}{l}\text { Clinical relapse NA } \\
(\text { CDAI }>250 \text { or } \\
\text { CDAI 150-250 with } \\
>70 \text { rise from } \\
\text { baseline over two } \\
\text { consecutive } \\
\text { evaluations) }\end{array}$ & 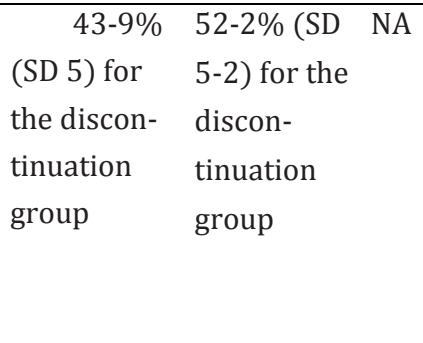 & $\begin{array}{l}\text { Median time } \\
16-4 \text { months }\end{array}$ & $\begin{array}{l}\text { Approximately a half of } \\
\text { patients with Crohn's } \\
\text { disease treated with at least } \\
1 \text { year of combination } \\
\text { therapy relapsed within } 1 \\
\text { year of anti-TNF withdrawal }\end{array}$ \\
\hline
\end{tabular}




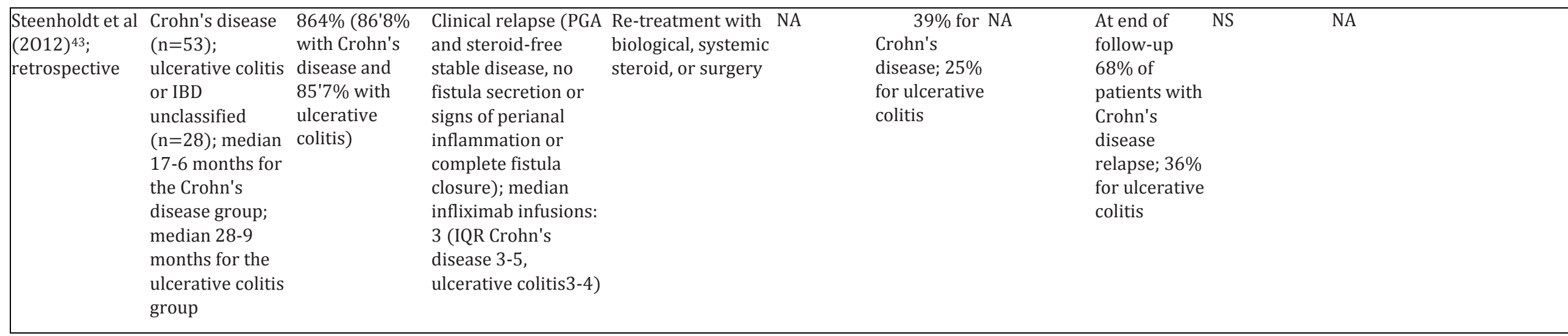

$\mathrm{IBD}=$ inflammatory bowel disease. $\mathrm{CDAI}=$ Crohn's Disease Activity Index. $\mathrm{PGA}=$ patient global assessment. $\mathrm{NA}=$ not applicable. NS=not specified. Unless otherwise specified the duration of follow-up was the same at the duration of the RCT and is the same for all participants.

Table 4: Studies of re-treatment with anti-TN F agents

\begin{tabular}{|c|c|c|c|c|c|c|}
\hline & Participants & $\begin{array}{l}\text { Concurrent Time to relapse } \\
\text { immunomod } \\
\text { ulators } \\
(\%)\end{array}$ & $\begin{array}{l}\text { Re- } \\
\text { treatment } \\
\text { with } \\
\text { biological } \\
\text { agent(\%) }\end{array}$ & $\begin{array}{l}\text { Achieved remission and the time to } \\
\text { remission (\%) }\end{array}$ & Adverse effects & Notes \\
\hline $\begin{array}{l}\text { Casanova et a } \\
(2017)^{51} ; \\
\text { retrospective }\end{array}$ & $\begin{array}{l}\text { IBD }(\mathrm{N}=1055 ; \\
\text { Crohn's disease } \\
{[\mathrm{n}=731] \text { and }} \\
\text { ulcerative colitis } \\
[\mathrm{n}=324])\end{array}$ & $\begin{array}{l}\text { 68\% (after Median of } 11 \text { months } \\
\text { biological } \\
\text { withdrawal) }\end{array}$ & $78 \%$ & $\begin{array}{l}67 \% \text { clinical remission at } 14 \text { weeks } \\
\text { and } 75 \% \text { in clinical remission and } \\
13 \% \text { partial response at end of } \\
\text { follow-up (median follow-up time } \\
19 \text { months) }\end{array}$ & $\begin{array}{l}\text { Allergic reactions } \\
(5 \%)\end{array}$ & $\begin{array}{l}3 \% \text { of patients who relapsed went to surgery; } \\
\text { similar results were found in patients in deep } \\
\text { remission: } 78 \% \text { in clinical remission and 15\% } \\
\text { partial response at end of follow-up }\end{array}$ \\
\hline $\begin{array}{l}\text { Reenaers et a } \\
(2018)^{50} ; \\
\text { retrospective }\end{array}$ & $\begin{array}{l}\text { Crohn's disease } \\
(\mathrm{n}=102)\end{array}$ & $\begin{array}{l}100 \% \text { (after Median of } 13 \text { months } \\
\text { biological } \\
\text { withdrawal) }\end{array}$ & $71 \%$ & $\begin{array}{l}66 \% \text { of those without infliximab } \\
\text { restart failure (no acute or delayed } \\
\text { infusion reaction, non-response, } \\
\text { loss of response, or infliximab- }\end{array}$ & NS & $\begin{array}{l}18 \text { patients had major complications a median of } \\
50 \text { months after stopping infliximab; } 22 \text { did not } \\
\text { restart infliximab or need another biological } \\
\text { (follow-up }\end{array}$ \\
\hline
\end{tabular}




\begin{tabular}{|c|c|c|c|c|c|c|c|}
\hline $\begin{array}{l}\text { Kennedy et al } \\
(2016)^{46 ;} \\
\text { retrospective }\end{array}$ & $\begin{array}{l}\text { IBD }(\mathrm{N}=166 \text {; Crohn's } \\
\text { disease }[\mathrm{n}=146] \text { and } \\
\text { ulcerative colitis or } \\
\text { IBD unclassified } \\
[\mathrm{n}=20])\end{array}$ & $\begin{array}{l}66.3 \% \text { with } \\
\text { IBD: 66\% } \\
\text { with } \\
\text { Crohn's } \\
\text { disease and } \\
75 \% \text { with } \\
\text { ulcerative } \\
\text { colitis }\end{array}$ & NS & $\begin{array}{l}75 \% \text { of } \\
\text { those with } \\
\text { Crohn's } \\
\text { disease and } \\
33 \% \text { of } \\
\text { those with } \\
\text { ulcerative } \\
\text { colitis }\end{array}$ & $\begin{array}{l}93 \% \text { successful in those with } \\
\text { Crohn's disease and } 67 \% \text { successful } \\
\text { of those with ulcerative colitis; } \\
\text { timepoint NS }\end{array}$ & NS & $\begin{array}{l}40 \% \text { of patients with Crohn's disease needed } \\
\text { steroids and } 4 \% \text { surgery }\end{array}$ \\
\hline $\begin{array}{l}\text { Monterubbian } \\
\text { esi et al } \\
(2015)^{79} \\
\text { retrospective }\end{array}$ & $\begin{array}{l}\text { Crohn's disease } \\
(\mathrm{N}=58)\end{array}$ & $66 \%$ & NS & $52 \%$ & $\begin{array}{l}\text { 633\% clinical remission; time point } \\
\text { NS }\end{array}$ & $\begin{array}{l}\text { Loss of response in } \\
27 \% \text { and infusion } \\
\text { reaction in } 10 \%\end{array}$ & NA \\
\hline $\begin{array}{l}\text { Dai et al } \\
(2014)^{53} ; \\
\text { prospective }\end{array}$ & $\begin{array}{l}\text { IBD }(\mathrm{N}=218 ; \text { Crohn's } \\
\text { disease }[\mathrm{n}=109] ; \\
\text { ulcerative colitis or } \\
\text { IBD unclassified } \\
[\mathrm{n}=107))\end{array}$ & $\begin{array}{l}30.6 \% \text { with } \\
\text { IBD: } 41 \% \\
\text { with } \\
\text { Crohn's } \\
\text { disease and } \\
20 \% \text { with } \\
\text { ulcerative } \\
\text { colitis }\end{array}$ & $\begin{array}{l}\text { Median of 4'8 months } \\
\text { for those with } \\
\text { Crohn's disease; } \\
\text { median of 6-7 } \\
\text { months for those } \\
\text { with ulcerative colitis }\end{array}$ & $\begin{array}{l}100 \% \text { for } \\
\text { both groups }\end{array}$ & $\begin{array}{l}\text { 783\% clinical response (mean } 3 \\
\text { months) in those with Crohn's } \\
\text { disease; } 667 \% \text { clinical response } \\
\text { (mean } 3 \text { months) in those with } \\
\text { ulcerative colitis }\end{array}$ & NS & NA \\
\hline $\begin{array}{l}\text { Farkas et al } \\
(2014)^{54 ;} \\
\text { prospective }\end{array}$ & $\begin{array}{l}\text { IBD }(\mathrm{N}=47 ; \text { Crohn's } \\
\text { disease }[\mathrm{n}=35] ; \\
\text { ulcerative colitis } \\
[\mathrm{n}=12])\end{array}$ & $81 \%$ & NS & NS & $\begin{array}{l}81 \% \text { clinical response in those with } \\
\text { Crohn's disease; } 54 \% \text { clinical } \\
\text { response in those with ulcerative } \\
\text { colitis } \\
\text { ( } 2 \text { months) }\end{array}$ & NS & $\mathrm{NA}$ \\
\hline
\end{tabular}




\begin{tabular}{|c|c|c|c|c|c|c|c|}
\hline $\begin{array}{l}\text { Chauvin et al } \\
(2014)^{55} ; \\
\text { prospective }\end{array}$ & $\begin{array}{l}\text { Crohn's disease } \\
(\mathrm{N}=92)\end{array}$ & $100 \%$ & $\begin{array}{l}\text { Median of } 327 \\
\text { months for the } \\
\text { induction group; } \\
\text { median of } 15-9 \\
\text { months for the } \\
\text { maintenance group }\end{array}$ & $80 \%$ & $\begin{array}{l}89 \% \text { clinical remission, } 72 \% \\
\text { remained in steroid-free remission } \\
\text { (median } 1.2 \text { years [IQR } 0.3-2.4] \text { ) }\end{array}$ & NS & NA \\
\hline $\begin{array}{l}\text { Brooks et al } \\
(2014)^{\text {so; }} \\
\text { prospective }\end{array}$ & $\begin{array}{l}\text { Crohn's disease } \\
(\mathrm{N}=86)\end{array}$ & $80 \%$ & Mean of 7-5 months & $86 \%$ & $\begin{array}{l}\text { 93\% initial response and } 92 \% \text { in } \\
\text { clinical remission after } 1 \text { year of } \\
\text { follow-up }\end{array}$ & $\begin{array}{l}\text { Neutropenia (in } \\
\text { two patients) }\end{array}$ & NA \\
\hline $\begin{array}{l}\text { Molander et a } \\
(2014)^{44} ; \\
\text { prospective }\end{array}$ & $\begin{array}{l}\text { IBD }(\mathrm{N}=52 ; \text { Crohn's } \\
\text { disease }[\mathrm{n}=17] \\
\text { ulcerative colitis or } \\
\text { IBD unclassified } \\
[\mathrm{n}=35])\end{array}$ & $\begin{array}{l}71 \% \text { with } \\
\text { Crohn's } \\
\text { disease; } \\
86 \% \text { with } \\
\text { ulcerative } \\
\text { colitis }\end{array}$ & NS & $88 \%$ & $\begin{array}{l}\text { 93\% in clinical remission ( } 3 \\
\text { months); } 90 \% \text { clinical remission } \\
\text { (12 months) for both groups of } \\
\text { patients }\end{array}$ & $\begin{array}{l}\text { No serious adverse } \\
\text { effects }\end{array}$ & NA \\
\hline $\begin{array}{l}\text { Molnaretal } \\
(2013)^{56} ; \\
\text { prospective }\end{array}$ & $\begin{array}{l}\text { Crohn's disease } \\
(\mathrm{N}=121)\end{array}$ & $83.6 \%$ & Median of 6 months & $100 \%$ & $547 \%$ clinical remission & $\begin{array}{l}\text { Mild side-effects in } \\
4 \% \text { and infusion } \\
\text { reaction in } 6 \%\end{array}$ & NA \\
\hline $\begin{array}{l}\text { Louis et al } \\
(2012)^{49} \\
\text { prospective }\end{array}$ & $\begin{array}{l}\text { Crohn's disease } \\
(\mathrm{N}=115)\end{array}$ & $100 \%$ & $\begin{array}{l}\text { Median of } 16.4 \\
\text { months }\end{array}$ & $100 \%$ & $\begin{array}{l}\text { Before third infliximab infusion: } \\
88 \%(38 / 43) \text { clinical remission and } \\
98 \%(42 / 43) \text { clinical response }\end{array}$ & NS & NA \\
\hline
\end{tabular}

$\mathrm{IBD}=$ inflammatory bowel disease. $\mathrm{NS}=$ not specified. $\mathrm{NA}=$ not applicable. 


\section{References}

1 Peyrin-Biroulet L, Sandborn W, Sands BE, et al. Selecting therapeutic targets in inflammatory bowel disease (STRIDE): determining therapeutic goals for treat-to-target. Am J Gastroenterol 2015; 110: 1324-38.

2 Colombel J-F, Panaccione R, Bossuyt P, et al. Effect of tight control management on Crohn's disease (CALM): a multicentre, randomised, controlled phase 3 trial. Lancet 2017; 390: 2779-89.

3 Khanna R, Bressler B, Levesque BG, et al. Early combined immunosuppression for the management of Crohn's disease (REACT): a cluster randomised controlled trial. Lancet2015; 386: 1825-34.

4 Bemelman WA, Warusavitarne J, Sampietro GM, et al. ECCO guideline/consensus paper ECCO-ESCP consensus on surgery for Crohn's disease. J Crohns Colitis 2018; 12: 1-16.

5 Van Der Woude CJ, Ardizzone S, Bengtson MB, et al.

ECCO guidelines/consensus paper the second european evidenced-based consensus on reproduction and pregnancy in inflammatory bowel disease. J Crohns Colitis 2015; 9: 107-24.

6 Gomollón F, Dignass A, Annese V, et al. 3rd European evidence-based consensus on the diagnosis and management of Crohn's disease 2016: part 1: diagnosis and medical management. J Crohns Colitis 2017; 11: 03-25.

7 Harbord M, Eliakim R, Bettenworth D, et al. Third european evidence-based consensus on diagnosis and management of ulcerative colitis. Part 2: current management. J Crohns Colitis 2017; 11: 769-84.

8 Torres J, Mehandru S, Colombel J-F, Peyrin-Biroulet L. Crohn's disease. Lancet 2017; 389: 1741-55

9 Beaugerie L, Kirchgesner J. Balancing benefit vs risk of immunosuppressive therapy for individual patients with inflammatory bowel diseases. Clin Gastroenterol Hepatol 2019; 17: 370-79.

10 Lemaitre M, Kirchgesner J, Rudnichi A, et al. Association between use of thiopurines or tumor necrosis factor antagonists alone or in combination and risk of lymphoma in patients with inflammatory bowel disease. JAMA 2017; 318: 1679-86.

11 Kirchgesner J, Lemaitre M, Carrat F, Zureik M, Carbonnel F, Dray-Spira R. Risk of serious and opportunistic infections associated with treatment of inflammatory bowel diseases. Gastroenterology 2018; 155: 337-46.

12 Beaugerie L, Brousse N, Bouvier AM, et al. Lymphoproliferative disorders in patients receiving thiopurines for inflammatory bowel disease: a prospective observational cohort study. Lancet 2009; 374: 1617-25.

13 van der Valk M, Mangen M, Leenders M, et al. Healthcare costs of inflammatory bowel disease have shifted from hospitalisation and surgery towards anti-TNFa therapy: results from the COIN study. Gut 2014; 63: 72-79.

14 Vande Casteele N, Ferrante M, Van Assche G, et al.

Trough concentrations of infliximab guide dosing for patients with inflammatory bowel disease. Gastroenterology 2015; 148: 1320-29.

15 Attar A, Duru G, Roblin X, et al. Cost savings using a test-based de-escalation strategy for patients with Crohn's disease in remission on optimized infliximab: a discrete event model study. Dig Liver Dis 2019; 51: 112-19.

16 Wenzl HH, Primas C, Novacek G, et al. Withdrawal of long-term maintenance treatment with 
azathioprine tends to increase relapse risk in patients with Crohn's disease. Dig Dis Sci2015;

60: $1414-23$.

17 Lémann M, Mary JY, Colombel JF, et al. A randomized, double-blind, controlled withdrawal trial in Crohn's disease patients in long-term remission on azathioprine. Gastroenterology 2005; 128: 181218.

18 Vilien M, Dahlerup JF, Munck LK, Nørregaard P, Grønbaek K, Fallingborg J. Randomized controlled azathioprine withdrawal after more than two years treatment in Crohn's disease: increased relapse rate the following year. Aliment Pharmacol Ther 2004; 19: 1147-52.

19 Hawthorne AB, Logan RF, Hawkey CJ, et al. Randomised controlled trial of azathioprine withdrawal in ulcerative colitis. BMJ1992;

305: 20-22.

20 O’Donoghue DP, Dawson AM, Powell-Tuck J, Bown RL, Lennard-Jones JE. Double-blind withdrawal trial of azathioprine as maintenance treatment for Crohn's disease. Lancet 1978; 2: 955-57.

21 Roblin X, Boschetti G, Williet N, et al. Azathioprine dose reduction in inflammatory bowel disease patients on combination therapy: an open-label, prospective and randomised clinical trial. Aliment Pharmacol Ther 2017; 46: 142-49.

22 Fischer M, Campbell SC, Calley CSJ, Helper DJ, Chiorean MV, Fadda HM. Risk factors for rescue therapy in Crohn's patients maintained on infliximab after withdrawal of the immunomodulator: a long-term follow-up. Dig Dis Sci 2017; 62: 3131-37.

23 Kierkuś J, Iwańczak B, Wegner A, et al. Monotherapy with infliximab versus combination therapy in the maintenance of clinical remission in children with moderate to severe Crohn disease. J Pediatr Gastroenterol Nutr 2015; 60: 580-85.

24 Filippi J, Laharie D, Michiels C, et al. Efficacy of sustained combination therapy for at least 6 months with thiopurines and infliximab in patients with ulcerative colitis in clinical remission:

a retrospective multicenter French experience. J Crohns Colitis 2015; 9: 252-58.

25 Drobne D, Bossuyt P, Breynaert C, et al. Withdrawal of immunomodulators after co-treatment does not reduce trough level of infliximab in patients with Crohn's disease.

Clin Gastroenterol Hepatol 2015; 13: 514-21.

26 Choi G, Park D, Park J, et al. Withdrawal of azathioprine in luminal Crohn's disease treated with infliximab maintenance therapy:

a retrospective case-control study (abstr). J Gastroenterol Hepatol 2010; 25: A86.

27 Oussalah A, Chevaux JB, Fay R, Sandborn WJ, Bigard MA, Peyrin-Biroulet L. Predictors of infliximab failure after azathioprine withdrawal in Crohn's disease treated with combination therapy. $\mathrm{Am} J$ Gastroenterol 2010; 105: 1142-49.

28 Sokol H, Seksik P, Nion-Larmurier I, et al. Withdrawal of immunosuppression in inflammatory bowel disease treated with infliximab maintenance therapy. Gastroenterology2009; 136: A187-88.

29 Van Assche G, Magdelaine-Beuzelin C, D’Haens G, et al. Withdrawal of immunosuppression in Crohn's disease treated with scheduled infliximab maintenance: a randomized trial. Gastroenterology 2008; 134: 1861-68.

30 Torres J, Boyapati R, Kennedy N, Louis E, Colombel J, Satsangi J. Systematic review of effects of withdrawal of immunomodulators or biologic agents from patients with inflammatory bowel disease. Gastroenterology 2015; 149: 1716-30.

31 Treton X, Bouhnik Y, Mary JY, et al. Azathioprine withdrawal in patients with Crohn's disease 
maintained on prolonged remission: a high risk of relapse. Clin Gastroenterol Hepatol 2009; 7: 80-85.

32 Boyapati R, Torres J, Palmela C, et al. Withdrawal of immunosuppressant or biologic therapy for patients with quiescent Crohn's disease. Cochrane Database Syst Rev2018; 12: CD012540.

33 Fraser AG, Morton D, McGovern D, Travis S, Jewell DP.

The efficacy of methotrexate for maintaining remission in inflammatory bowel disease. Aliment Pharmacol Ther 2002; 16: 693-97.

34 Hisamatsu T, Kato S, Kunisaki R, et al. Withdrawal of thiopurines in Crohn's disease treated with scheduled adalimumab maintenance: a prospective randomised clinical trial (DIAMOND2). ECCO; Copenhagen, Denmark; March 6-9, 2019. DOP32.

35 Kennedy NA, Heap GA, Green HD, et al. Predictors of anti-TNF treatment failure in anti-TNF-naive patients with active luminal Crohn's disease: a prospective, multicentre, cohort study. Lancet Gastroenterol Hepatol 2019; 4: 341-53.

36 Vermeire S, Gils A, Accossato P, Lula S, Marren A. Immunogenicity of biologics in inflammatory bowel disease. Therap Adv Gastroenterol 2018; 11: 1-13.

37 Nanda K, Cheifetz A, Moss A. Impact of antibodies to infliximab on clinical outcomes and serum infliximab levels in patients with inflammatory bowel disease (IBD): a meta-analysis. Am J Gastroenterol 2013; 108: 40-47.

38 Karmiris K, Paintaud G, Noman M, et al. Influence of trough serum levels and immunogenicity on longterm outcome of adalimumab therapy in Crohn's disease. Gastroenterology 2009; 137: 1628-40.

39 Yarur AJ, Kubiliun MJ, Czul F, et al. Concentrations of 6-thioguanine nucleotide correlate with trough levels of infliximab in patients with inflammatory bowel disease on combination therapy. Clin Gastroenterol Hepatol 2015; 13: 1118-24.

40 Ungar B, Chowers Y, Yavzori M, et al. The temporal evolution of antidrug antibodies in patients with inflammatory bowel disease treated with infliximab. Gut 2014; 63: 1258-64.

41 Drobne D, Kurent T, Golob S, et al. Optimised infliximab monotherapy is as effective as optimised combination therapy, but is associated with higher drug consumption in inflammatory bowel disease. Aliment Pharmacol Ther 2019; 49: 880-89.

42 Lega S, Phan BL, Rosenthal CJ, et al. Proactively optimized infliximab monotherapy is as effective as combination therapy in IBD proactively optimized infliximab monotherapy is as effective as combination therapy in IBD. Inflamm Bowel Dis 2019; 1: 134-41.

43 Steenholdt C, Molazahi A, Ainsworth MA, Brynskov J, Thomsen OØ, Seidelin JB. Outcome after discontinuation of infliximab in patients with inflammatory bowel disease in clinical remission: an observational Danish single center study.

Scand J Gastroenterol 2012; 47: 518-27.

44 Molander P, Färkkilä M, Salminen K, et al. Outcome after discontinuation of TNFa-blocking therapy in patients with inflammatory bowel disease in deep remission. Inflamm Bowel Dis 2014; 20: 1021-28.

45 Sorrentino D, Nash P, Viladomiu M, Hontecillas R. Stopping anti-TNF agents in patients with Crohn's disease in remission: is it a feasible long-term strategy? Inflamm Bowel Dis 2014; 20: 757-66.

46 Kennedy NA, Warner B, Johnston EL, et al. Relapse after withdrawal from anti-TNF therapy for inflammatory bowel disease: an observational study, plus systematic review and meta-analysis. Aliment Pharmacol Ther 2016; 43: 910-23.

47 Papamichael K, Vermeire S. Withdrawal of anti-tumour alfa necrosis factor therapy in inflammatory bowel disease. 
World J Gastroenterol 2015; 21: 4773-78.

48 Frias Gomes C, Colombel J-F, Torres J. De-escalation of therapy in inflammatory bowel disease. Curr Gastroenterol Rep 2018; 20: 35.

49 Louis E, Mary J, Vernier-massouille G, et al. Maintenance of remission among patients with Crohn's disease on antimetabolite therapy after infliximab therapy is stopped. Gastroenterology 2012; 142: 63-70.

50 Reenaers C, Mary J, Nachury M, et al. Outcomes 7 years after infliximab withdrawal for patients with Crohn's disease in sustained remission. Clin Gastroenterol Hepatol 2018; 16: 234-43.

51 Casanova MJ, Chaparro M, Garciá-Sánchez V, et al. Evolution after Anti-TNF discontinuation in patients with inflammatory bowel disease: a multicenter long-term follow-up study. Am J Gastroenterol 2017; 112: 120-31.

52 Papamichael K, Vande Casteele N, Gils A, et al. Long-term outcome of patients with Crohn's disease who discontinued infliximab therapy upon clinical remission. Clin Gastroenterol Hepatol 2015; 13: 110310.

53 Dai C, Liu WX, Jiang M, Sun MJ. Mucosal healing did not predict sustained clinical remission in patients with IBD after discontinuation of one-year infliximab therapy. PLoS One 2014; 9: $1-6$.

54 Farkas K, Lakatos PL, Szucs M, et al. Frequency and prognostic role of mucosal healing in patients with Crohn's disease and ulcerative colitis after one-year of biological therapy. World J Gastroenterol 2014; 20: 2995-3001.

55 Chauvin A, Le A, Belhassan M, Le Y. Infliximab as a bridge to remission maintained by antimetabolite therapy in Crohn's disease: a retrospective study. Dig Liver Dis 2014; 46: 69 5-700.

56 Molnár T, Lakatos PL, Farkas K, et al. Predictors of relapse in patients with Crohn's disease in remission after 1 year of biological therapy. Aliment Pharmacol Ther 2013; 37: 225-33.

57 Gisbert JP, Marín AC, Chaparro M. The risk of relapse after anti-TNF discontinuation in inflammatory bowel disease: systematic review and meta-analysis. Am J Gastroenterol 2016; 111: 632-647.

58 Fiorino G, Cortes PN, Ellul P, et al. Discontinuation of infliximab in patients with ulcerative colitis is associated with increased risk of relapse: a multinational retrospective cohort study. Clin Gastroenterol Hepatol 2016; 14: 1426-32.e1.

59 Kotlyar DS, Osterman M, Diamond R, et al. A systematic review of factors that contribute to hepatosplenic T-cell lymphoma in patients with inflammatory bowel disease. Clin Gastroenter 2011; 9: $36-41$.

60 Doherty G, Katsanos KH, Burisch J, et al. European Crohn's and Colitis Organisation topical review on treatment withdrawal (exit strategies) in inflammatory bowel disease. JCrohns Colitis 2018; 5: 17-31.

61 Molnar T, Farkas K, Miheller P et al. Is the efficacy of successful infliximab induction therapy maintained for one year lasting without retreatment in different behavior types of Crohn's disease? J Crohns Colitis 2008; 2: 322-26.

62 Domènech E, Hinojosa J, Nos P, et al. Clinical evolution of luminal and perianal Crohn's disease after inducing remission with infliximab: how long should patients be treated?

Aliment Pharmacol Ther 2005; 22: 1107-13.

63 Mooiweer E, Severs M, Schipper MEI, Fidder HH, Siersema PD, Laheij RJF. Low fecal calprotectin predicts sustained clinical remission in inflammatory bowel disease patients: a plea for deep remission. JCrohns Colitis 2015; 9: 50-55. 
64 Kennedy NA, Kalla R, Warner B, et al. Thiopurine withdrawal during sustained clinical remission in inflammatory bowel disease: relapse and recapture rates, with predictive factors in 237 patients. Aliment Pharmacol Ther 2014; 40: 1313-23.

65 Zenlea T, Yee E, Rosenberg L, et al. Histology grade is independently associated with relapse risk in patients with ulcerative colitis in clinical remission: a prospective study. Am J Gastroenterol 2016; 111: 685-90.

66 Echarri A, Ollero V, Rodriguez J, Gallego J, Castro J. Predictors of relapse after discontinuing anti-TNF therapy in Crohn's disease patients on deep remission JCrohns Colitis 2013; 7: S171.

67 Bortlik M, Duricova D, Machkova N, Hruba V, Lukas M, Mitrova K. Discontinuation of anti-tumor necrosis factor therapy in inflammatory bowel disease patients: a prospective observation. Scand J Gastroenterol 2016; 51: 196-202.

68 Rajca S, Grondin V, Louis E, et al. Alterations in the intestinal microbiome (dysbiosis) as a predictor of relapse after infliximab withdrawal in Crohn's disease. Inflamm Bowel Dis 2014; 20: 978-86.

69 Lennard L, Thomas S, Harrington CI, Maddocks JL. Skin cancer in renal transplant recipients is associated with increased concentrations of 6-thioguanine nucleotide in red blood cells. Br J Dermatol 1985; 113: 723-29.

70 Na R, Laaksonen MA, Grulich AE, et al. Iatrogenic immunosuppression and risk of non-Hodgkin lymphoma in solid organ transplantation: a population-based cohort study in Australia. Br J Haematol 2016; 174: 550-62.

71 Jani M, Dixon, WG Lunt M, De Cock D. The association of biologic drug-levels with infection risk: results from the British Society for Rheumatology biologics register for rheumatoid arthritis. Ann Rheum Dis 2018; 77 (suppl 2): 163-64.

72 Petitcollin A, Brochard C, Siproudhis L, et al. Pharmacokinetic parameters of infliximab influence the rate of relapse after de-escalation in adults with inflammatory bowel diseases. Clin Pharmacol Ther 2019; 106: 605-15.

73 Lucidarme C, Petitcollin A, Brochard C, et al. Predictors of relapse following infliximab de-escalation in patients with inflammatory bowel disease: the value of a strategy based on therapeutic drug monitoring. Aliment Pharmacol Ther 2019; 49: 147-54.

74 Van Steenbergen S, Bian S, Vermeire S, Van Assche G, Gils A, Ferrante M. Dose de-escalation to adalimumab 40 mg every 3 weeks in patients with Crohn's disease-a nested case-control study. Aliment Pharmacol Ther 2017; 45: 923-32.

75 Baert F, Glorieus E, Reenaers C, et al. Adalimumab dose escalation and dose de-escalation success rate and predictors in a large national cohort of Crohn's patients. JCrohns Colitis 2013;

7: 154-60.

76 Schreiber S, Panés J, Louis E, Holley D, Buch M, Paridaens K. Perception gaps between patients with ulcerative colitis and healthcare professionals: an online survey. BMC Gastroenterol 2012; 15: 108.

77 De Suray N, Salleron J, Vernier-Massouille G, Grimaud JC, Bouhnik Y, Laharie D. P274 Close monitoring of CRP and fecal calprotectin levels to predict relapse in Crohn's disease patients. A sub-analysis of the STORI study. J Crohns Colitis 2012;

6: S118-19.

78 Molander P, Farkkila M, Ristimäki A, et al. Does fecal calprotectin predict short-term relapse after stopping TNFa-blocking agents in inflammatory bowel disease patients in deep remission?

J Crohns Colitis 2015; 9: 3340. 
79 Monterubbianesi, R Papi, C Kohn A. P529. Maintenance of clinical remission in Crohn's disease patients after discontinuation of antiTNF agents: results from a single centre cohort. J Crohns Colitis 2015; 9 (suppl 1): S345.

80 Brooks AJ, Sebastian S, Cross SS, et al. Outcome of elective withdrawal of anti-tumour necrosis factor- $\alpha$ therapy in patients with Crohn's disease in established remission. JCrohns Colitis 2014;

11: $1456-62$.

81 Molander P, Farkkila M, Kemppainen H, et al. Long-term outcome of inflammatory bowel disease patients with deep remission after discontinuation of TNFalpha-blocking agents. Scand $J$ Gastroenterol 2017; 52: 284-90.

82 Baert F, Drobne D, Gils A, et al. Early trough levels and antibodies to infliximab predict safety and success of reinitiation of infliximab therapy. Clin Gastroenterol Hepatol 2014; 12: 1474-81.e2.

83 Vermeire S, Loftus EV Jr, Colombel JF, et al. Long-term efficacy of vedolizumab for Crohn's disease. J Crohns Colitis 2017; 11: 412-24.

84 Louis E. Stopping biologics in IBD—what is the evidence? Inflamm Bowel Dis 2018; 24: 725-31.

85 Papamichael K, Vande Casteele N, Gils A, et al. Long-term outcome of patients with Crohn's disease who discontinued infliximab therapy upon clinical remission. Clin Gastroenterol Hepatol 2015; 13: 1103-10.

86 Siegel C, Thompson KD, Walls D, Gollins J, Colombel JF, Louis E. International differences in gastroenterologists' perspective on stopping the. ECCO; Barcelona, Spain; Feb 15-18, 2017. DOP015.

87 Siegel C, Thompson K, Walls D, et al. Crohn's disease patients' perspectives towards de-escalating immunosuppressive therapy:

a comparative French and American survey. ECCO; Vienna, Austria; Feb 14-17, 2018. DOP032.

88 NICE. Infliximab, adalimumab and golimumab for treating moderately to severely active ulcerative colitis after the failure of conventional therapy. 2015. https://www.nice.org.uk/guidance/ ta329 (accessed February 7, 2019).

89 NICE. Crohn's disease: management. 2012. https://www.nice.org. uk/guidance/cg152 (accessed February 7, 2019).

90 Buhl S, Steenholdt C, Brynskov J, Thomsen 0, Bendtzen K, Ainsworth M. Discontinuation of infliximab therapy in patients with Crohn's disease in sustained complete remission (the STOP IT study): protocol for a double-blind, randomised, placebo-controlled, multicentre trial. BMJ Open 2014; 4: 1-8.

91 Lee JC, Biasci D, Roberts R, et al. Genome-wide association study identifies distinct genetic contributions to prognosis and susceptibility in Crohn's disease. Nat Genet 2017; 49: 262-68.

92 Lee JC, Lyons PA, Mckinney EF, et al. Gene expression profiling of CD8+ T cells predicts prognosis in patients with Crohn disease and ulcerative colitis. JClin Invest 2011; 121: 4170-79.

93 West NR, Hegazy AN, Owens BMJ, et al. Oncostatin M drives intestinal inflammation in mice and its abundance predicts response to tumor necrosis factor-neutralizing therapy in patients with inflammatory bowel disease. Nat Med 2017; 23: 579-89.

93 Gobbi FL, Bandinelli F, Infantino M, Grossi V, Noguier G, Meacci F. Correlation between HLA haplotypes and the development of antidrug antibodies in a cohort of patients with rheumatic diseases. Biol Ther 2018; 12: 37-41.

95 Bartelds GM, Wijbrandts CA, Nurmohamed MT, et al. Anti-adalimumab antibodies in rheumatoid arthritis patients are associated with interleukin-10 gene polymorphisms. Arthritis Rheum 2009; 60: 2541-42. 
96 Sazonovs A, Kennedy N, Moutsianas L, et al. HLA-DQA1*05 is associated with the development of antibodies to anti-TNF therapy. bioRxiv 2018; published online Sept 9. DOI:10.1101/410035 (preprint).

97 de Jong MJ, van der Meulen-de Jong AE, Romberg-camps MJ, et al. Telemedicine for management of inflammatory bowel disease (myIBDcoach): a pragmatic, multicentre, randomised controlled trial. Lancet 2017; 390: 959-68.

98 White JR, Philips F, Monaghan T, et al. Novel oral-targeted therapies in inflammatory bowel disease. Aliment Pharmacol Ther 2018; 47: 1610-22.

99 Panes J, Bressler B, Colombel J, et al. Efficacy and safety of tofacitinib retreatment for ulcerative colitis after treatment interruption: results from the OCTAVE clinical trials. ECCO; Vienna, Austria; Feb 1417, 2018. P516. 